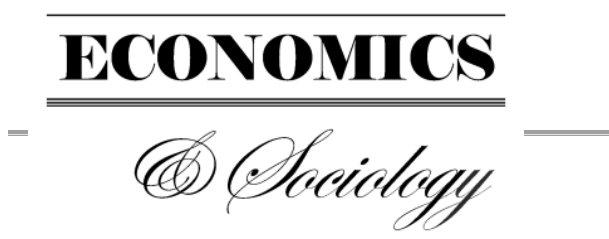

Lechman, E. (2019). Still 'few, slow and low'? On the female dimension of technology, labour markets and economic activity: Evidence for the period of 1990-2017. Economics and Sociology, 12(1), 11-38. doi:10.14254/2071-

789X.2019/12-1/1

\title{
STILL 'FEW, SLOW AND LOW'? ON THE FEMALE DIMENSION OF TECHNOLOGY, LABOUR MARKETS AND ECONOMIC ACTIVITY: EVIDENCE FOR THE PERIOD OF 1990-2017
}

\author{
Ewa Lechman, \\ Gdansk University of Technology, \\ Faculty of Management and \\ Economics, \\ Gdańsk, Poland, \\ E-mail:ewalechm@pg.edu.pl \\ ORCID: 0000-0003-1718-7134
}

Received: October, 2018 1st Revision: December, 2018 Accepted: February, 2019

DOI: $10.14254 / 2071-$ 789X.2019/12-1/1

\begin{abstract}
The known in empirical economics question 'Why so Few? Why so Slow? Why so Low?' refers here to the persistently small number of women involved in innovative activities, the slowness of change in the inequalities between women and men in these fields, and women's continuing lower rank in business and academic positions. In developing countries, women`s labour and entrepreneurial activity remains an 'untapped resource' for economic growth. In recent years, the rising proportion of women participating in the labour market has drawn the attention of many scholars. This positive change towards mobilising previously unused human resources is perceived as one of the positive externalities enhanced by the seemingly boundless flow of information and communication technology. This research examines, from a macroperspective, the association between economic deployment of ICT, women`s labour market participation, and economic growth in 64 developing countries between 1990 and 2017. We rely on the macrodata extracted from the World Bank Development Indicators (2018), the World Bank Enterprise Survey, the World Development Reports and the World Telecommunication/ICT Indicators Database (2018). Our methodological framework, in addition to standard descriptive statistics, combines time trends, graphical non-parametric analysis and panel vector-autoregressive models.
\end{abstract}

Keywords: ICT, female labour, women, developing countries.

\author{
JEL Classification: O30, \\ $\mathrm{O} 40$
}

\section{Introduction}

In the period under study here, 1990-2017, all the countries of the world experienced an unprecedentedly rapid diffusion of new information and communication technologies (ICTs). Even economically backward countries displayed significant increases in the adoption and use of ICT: at the turn of the 1990s the presence of ICT in developing countries was negligible, but by 2017 no less than $98 \%$ of their population had access to mobile cellular telephony (ITU, 2018), and even in the least developed countries this share exceeded $70 \%$. 
Meanwhile, that same year $48 \%$ of the people in the developing world were using active mobile broadband networks, gaining unlimited access to all types of knowledge and information. This revolutionary change is certainly generating more profound changes in these economies and societies. The arrival of ICT and the start of its worldwide diffusion in the early 1980s gave rise to various social and economic changes, owing mainly to the unique characteristics of the technology. ICTs are recognised as general purpose technologies (GPTs - Bresnahan and Trajtenberg, 1995), meaning that they are 'enabling technologies' and that their adoption offers practically unlimited opportunities -- socially, institutionally and economically. They trigger profound changes and structural shifts. ICTs create a series of different networks (Shapiro and Varian, 1998; Valente, 1996; Castells et al., 2009), which enhance the exchange of information and knowledge and reshape the way people communicate and run their businesses. In economic terms, this means that the growing number of interpersonal links potentially translates into real gains by mobilising unused financial or labour resources. To some extent, the widespread deployment of ICT may gradually eradicate various forms of exclusion - social, economic, institutional, even political.

In the majority of developing economies women constitute an economically disadvantaged group. They are exposed to extreme poverty, suffer from low literacy rates, poor access to healthcare and education and also barriers in entry to formal labour market, as they are usually unpaid and unregistered workers. They are left behind, their economic potential remaining unused. Traditional societies tend to limit their economic and social mobility. Persistent religious and other prejudices continue to exclude female population from many social and economic activities. This constitutes a significant constraint on economic growth and development, and in fact in these countries women now represent untapped resources (Fielden et al., 2000; Andersson \& Hatakka, 2017). In many cases economic and social empowerment of women becomes a key to the implementation of various antipoverty programmes and plans to accelerate economic growth (see, for instance, Hafkin and Huyer, 2006; Islam, 2015; Afrah and Fabiha, 2017; Bandiera et al., 2017). As ICT has quickly become one of the key factors in national economies as in the global economy as such, it arguably offers women broad opportunities for empowerment. ICT may help women to gain literacy, education and professional training, skills that would enable them become active participants in the formal economy (Afshar, 2016; Cornwall, 2016). Ready activation of ICT helps women access healthcare systems and financial services, become economically engaged (Buvinic \& Furst-Nichols, 2014; Kabir, 2016; Kabeer, 2017).

This study augments our knowledge in two ways. First, it documents major changes in women empowerment that have taken place, using seven indicators of participation in economic life: namely, female employment in agriculture, female youth employment rate (ages 15-24), female self-employment, female vulnerable employment, female wage and salaried work, female contributing family workers and female labour force (as the share of the total labour force). Additionally, we consider girls' share in secondary school enrolment as the indicator of access to education. Second, we relate women empowerment to ICT deployment - approximated by the share of population using the Internet. Our major objective is to determine whether variations in women empowerment and in ICT use are correlated. Put differently, this study examines - from the macroeconomic perspective - changes in women's labour market participation in the context of expanding use of ICT in the economically backward countries. The sample encompasses 64 low- and lower-middle-income economies in the period from 1990 to 2017. All the statistical data are derived from the World Telecommunication/ICT Indicators Database 2016, the World Development Indicators 2017 and the International Labour Organization database 2017.

This paper comprises six logically structured sections. Section 2 below contextualises the research, presenting the main arguments and briefly reviewing the related literature. 
Section 3 describes the research method, while Section 4 discusses the data used for the analysis. Section 5, entirely empirical, sets out the results of the numerical analysis and interprets and discusses the outcomes. Section 6 concludes.

\section{Context and Background}

The question 'Why so Few? Why so Slow? Why so Low?' in the influential work of Ranga \& Etzkowitz (2010) referred to the persistently small number of women involved in innovative activities broadly defined, the slowness of change in the degree of inequality between women and men in these fields and women's generally lower rank in business and academic hierarchies. Here we can see the straightforward relationship between women`s socio-economic empowerment and their engagement in the formal labour market and business. Needless to say, especially in developing countries women's labour and entrepreneurial activities still remain an 'untapped resource' for economic growth and welfare. In recent years, the rising proportion of women in the labour market has drawn the notice of many scholars (Gaddis \& Klasen, 2014; Verick, 2014; Tsani et al., 2015; Allen and Truman, 2016; Drucker, 2017). This new mobilisation of unused human resources is perceived as one of the positive externalities produced by the massive introduction of ICTs, which as general purpose technologies (Bresnahan \& Trajtenberg, 1995) have a profound impact in all spheres of social and economic life. ICTs can be seen as unlocking the potential of women in general; more in particular they contribute, directly and indirectly, to women`s greater engagement in generating national output (through such means as higher labour force participation, self-employment, and leaving the informal sector). ICTs are known to make it easier to overcome various gender-specific constraints on entrepreneurial behaviour, such as lack of education and experience, high rates of involvement in unpaid family work and/or the informal economy, and limited ability to acquire financial assets. From now on there is no neglecting the role of ICT in fostering women`s entrepreneurial attitudes (Kaur, Lechman \& Marsz, 2017). ICTs are pervasive cutting-edge technologies that produce profound shifts and transformations in societies and economies. ICT, as an emerging techno-economic paradigm, has given rise to organisational and institutional change. Many claim that ICT was the prime catalyst of globalisation, making possible the incredibly rapid spread of information and knowledge and facilitating interpersonal communication between distant agents. Due to its disruptiveness and pervasiveness, ICT's effects cut across all sectors of the economy, bypass socio-economic systems and bring long-term productivity gains (Jovanovic \& Rousseau, 2005). That is, ICTs are held to be general purpose technologies (Bresnahan \& Trajtenberg, 1995). GPTs are 'prime-movers' of the economy; they produce positive externalities and welfare, but only if their diffusion is not restricted by the institutional framework or the inability of economic agents to absorb them. GPTs pave the way ahead and open up new opportunities: 'as GPTs appear [...] there is a spell of growth, with rising output, real wages, and profits' (Helpman \& Trajtenber, 1996, p.4). Gregory Clark writes that '...the biggest beneficiary of the Industrial Revolution has so far been the unskilled...' (Clark, 2008, p. 3). Recently, there has been widespread recognition of the opportunities that ICTs offer to developing economies, with emphasis on their special importance when deployed in lowincome and economically marginal societies. Perez and Soete (1988) say that ICTs are the windows of opportunity by means of which developing societies and economies are influenced, through various channels. The prime attribute of ICTs is their enablement of widespread communication and rapid and easy access to information and knowledge, critical prerequisites for long-term socioeconomic development (Hanna et al., 1995). Above all, ICTs may directly affect social and economic development by mobilising resources and reinforcing market activities. By allowing better access to financial markets (as via e-finance and mobile 
finance), ICTs foster the mobilisation of savings and provide opportunities to convert it into investment, which has long-term positive consequences for market activity and economic growth. At the same time ICTs facilitate greater mobilisation of the labour force, with multiple consequences. First, increased participation in formal labour markets provides a solid base for earning regular income. This moves people out of the subsistence economy, gradually alleviates poverty and reduces vulnerability to risk and external shocks. There is no question that greater engagement in labour markets, both through salaried employment and through small business start-ups, produces economic gains and allows for the gradual eradication of various forms of deprivation. Higher participation in the labour force is very likely to be the first, most important step for developing countries to exploit the full potential of ICT. Its deployment permits timely access to information, helping to overcome one of the fundamental barriers to the effective functioning of the market, namely information asymmetries. Combined appropriately, these two elements - shifting labour force participation and removing constraints on information access - lead to increases in the number of transactions, enable participation in global markets, reduce transaction costs and ensure worldwide visibility, all of which in the longer run offers better prospects for economic growth and development. Indirectly, ICTs may foster socioeconomic development though better access to education and knowledge, better and more effective healthcare systems (mainly e-health and telemedicine) and so-called e-government. All of these developments make for significant growth in human capital and skills, contribute to social cohesion, enhance the empowerment of all social groups (e.g. indigenous peoples), and ensure transparency and political inclusion. Obviously, the effect of ICTs on education and healthcare systems is qualitative in nature; the real gains emerge progressively in the form of social and economic advance. One of the most serious problems for economically backward countries is low female participation in the formal market economy, i.e. in the job market and entrepreneurial activities. Women`s relatively low rate of economic activity may be the direct effect of poor education, poor skills and illiteracy. Women in developing countries are often deprived of access to the financial system; they have no permanent income from contracted work. In traditional societies, a whole series of social or religious norms and attitudes often consign the female population to the status of 'hidden and usually unpaid' labour. Women are exposed to extreme poverty and often denied basic rights. In fact, to a great extent women in developing countries constitute an unused labour force, which may significantly impede national growth and development. According to World Bank estimates, for instance, in Africa almost $65 \%$ of the women outside agriculture are self-employed. Unfortunately, they tend to be engaged in informal home-based businesses, mostly in traditional activities, which usually require less seed capital and less experience, and accordingly yield lower returns and benefits. Although various studies have found a growing number of women worldwide who operate their own businesses, there are a number of regional and national determinants of female labour market participation. Evidently, in economically backward countries the main factor impelling women to set up their own businesses and become engaged in the formal labour market is necessity, not opportunity. In the absence of alternative ways of supplementing household income, entrepreneurship or self-employment is the only viable option. Additionally, women who want to engage in economic activity face various gender-specific constraints, such as barriers to education and lack of the combination of relevant education, professional skills and work experience, which may be a severe handicap not only in seeking decently paid jobs but also in forming businesses of their own. Additionally, especially in the less advanced countries, restricted access to technology and difficulty in financial market participation ('financial exclusion') are heavy barriers for women seeking to escape vulnerable, low-paid and indecent employment (Beneria et al., 2015). Moreover, in these countries women entrepreneurs mostly run home-based businesses in traditional, often 
informal, sectors, which are characterised by low effective demand, low profits and high exposure to risk and external shocks (Pryer, 2017). In developing countries, a significant share of women are 'just' inside workers. They are highly vulnerable, suffering from poor education and permanent material and institutional exclusion (Klasen et al., 2015). Verick (2018) claims that with respect to developing countries, the issues related to women participation in labour market are far more complex than, for instance, in high-income economies. He argues that due to various social and educational constrains girls and then adults are simply deprived from unbounded access to labour activities. He also raises that the simple and well-established relationships between female labour participation and e.g. economic growth that seem to be the U-shaped relationship, do not appear in low income economies. Similar claims may be traced in Lindio-McGovern and Williamann (2016) or Sachs (2018) where they argue that the problem of marginal women engagement in formal economic activities is especially sever in rural areas, where girls are simply denied to attend school and then 'condemned' to become unpaid family worker. In Klasen (2018 and 2018a), we find more arguments and explanation of female exclusion in labour market. He turns to show that social values and norms, structure of national economy but also state political regimes in developing countries can effectively hinder women participation on value added creation. In the same vein, in reference to Mexico, we find evidence in Ortiz and Pillai (2019).

\section{Methodological approach}

Our empirical strategy combines different analytical techniques that reveal the key features of the variables and the relationships among them. In addition to standard descriptive statistics, our methodological framework combines time trends, graphical non-parametric analysis and panel vector autoregressive modelling techniques.

First, we use density curves plotted by adopting non-parametric estimation of probability density functions of the form

$f(x)=\frac{d}{d x} F(x)$

where $F(x)$ represents the continuous distribution of random variable $X$. Density curves generated by the kernel density estimator are continuous and show an 'empirical' distribution of variables. To estimate the density of $\mathrm{f}(\mathrm{x})$, we use its discrete derivative, so the kernel estimator takes the general form:

$f^{\prime}(x)=\frac{1}{n h} \sum_{i=1}^{n} k\left(\frac{X_{i}-x}{h}\right)$,

where $k(u)$ is a kernel function that satisfies $\int_{-\infty}^{\infty} k(u) d u=1$. In our case $f^{\prime}(x)$ shows the percentage of observations located near $x$. If these are very numerous, then $f^{\prime}(x)$ is large; otherwise it is small. The specific kernel functions represent in-time changes in the distribution of each variable examined and allow for a preliminary pattern analysis.

Next, to reveal the statistical relationships between consecutive pairs of variables, we adopt a locally weighted polynomial smoother, which is a nonparametric method that graphically fits the curve displaying the relationship between two variables. This useful method is widely employed, as it allows one to relax the rigid assumptions of conventional parametric analysis, so that no assumption regarding the form of the relationships is made. A great advantage of using the locally weighted scatterplot smoothing method (LOWESS) is that it is outlier-resistant, introducing no disturbances in results. Following Cleveland (1979), we approximate a function with the general form:

$f($.

assuming that all the errors $e_{i}$ generated by the model are equal to zero. Having defined $x_{i}$ as one of the covariates, we can estimate $f($.$) by using the multivariate polynomial$ form, where the respective $x_{i}$ are chosen to extrapolate: 
$y_{i}=f\left(x_{i}^{*}\right)$,

if $i=1, \ldots \ldots k$, in the $k$-nearest neighborhood of $x^{*}$, with the underlying assumption that $f$ is a locally smooth function.

Furthermore, to examine potential quantitative relationships arising between the variables, we use panel model regressions and panel vector autoregression models (PVAR).

First, we try a fixed effects regression, which yields

$\varphi_{i y}=\alpha_{i}+\gamma_{1} x_{1 i y}+\cdots+\gamma_{n} x_{n i y}+\varepsilon_{i y}$,

where $i$ denotes the country and $y$ the year. Eq. (8) can be reformulated by introducing country dummies:

$\varphi_{i y}=\alpha_{i}+\gamma_{1} x_{1 i y}+\cdots+\gamma_{n} x_{n i y}+\delta_{2} C_{2}+\cdots+\delta_{n} C_{n}+\varepsilon_{i y}$.

In Eqs. (5) and (6), $\alpha_{\mathrm{i}}$ denotes unobserved and time-invariant fixed effects, $\delta_{n}$ is the coefficient for binary country regressors, $C$ is the country dummy and $n$ the number of countries. For Eqs. (5-6) to satisfy the exogeneity assumption, we assume that $E\left(\varepsilon_{i y} / x_{i y}\right.$, $\left.\alpha_{i}\right)=0$, if $x_{i y}$ stands for the explanatory variable. To confirm the adequacy of the fixed effects regression, we perform a Hausman test (Maddala and Lahiri, 2009), which verifies the null hypothesis $H_{0}: \operatorname{cov}\left(\alpha_{i}, x_{i y}\right)=0$ if a random effects regression is asymptotically more efficient than a fixed effects regression; otherwise fixed effects regression is more suitable. If the random effects model proves to be more appropriate, we estimate

$\varphi_{i y}=\gamma_{0}+\gamma_{1} x_{1 i y}+\cdots+\gamma_{n} x_{n i y}+\alpha_{i}+\varepsilon_{i y}$,

with notation analogous to Eqs. (5-6). As the name implies, random effects models assume that variation across countries (or other entities) is random, and hence not correlated with the explanatory variables.

Technically, a panel VAR model is constructed with the same logic as a standard VAR but with an added cross-sectional dimension. Suppose we have a cross-section of $Y$ sets of units (say, countries) and we presume that these are linked to each other. For each $y$-unit, we consider a set of $X$ economic variables over time. By definition in a panel VAR all the variables are endogenous, so each is assumed to depend on its own lagged values plus those of all the others in the model (Dées \& Guntner, 2014). Considering that a panel VAR model also accounts for the cross-sectional dimension, its equation has the general form (Dées \& Guntner, 2014)

$\gamma_{y, t}=v_{y}+\Omega_{1, y} \Gamma_{t-1}+\cdots+\Omega_{p, y} \Gamma_{t-p}+e_{y, t}$ if $y=1, \ldots \ldots, Y$.

In Eq. (9), $\gamma_{y, t}$ denotes the $(X \times 1)$ vector of endogenous variables for the $y$-unit examined; $t$ is time and $p$ the lags of the endogenous variables. $\Gamma_{t}=\left(\dot{\gamma}_{1, t}, \ldots, \dot{\gamma}_{N, t}\right)$ stands for the $(Y \cdot X \times 1)$ vector of $\gamma_{y, t}$ if $y=1, \ldots \ldots, Y . \Omega_{j, y}, j=1, \ldots \ldots, p, y=1, \ldots \ldots, Y$, represents $(X \times Y \cdot X)$ matrices of the slope coefficients of the endogenous variables, $v_{y}$ is the $(X \times 1)$ vector of intercepts and $e_{y, t}$ stands for the $(X \times 1)$ vector of contemporaneously correlated reduced-form coefficients (Dées and Guntner, 2014; Abrigo and Love, 2016).

However, $\Gamma_{t}$, which represents a $(Y \cdot X \times 1)$ vector, may depend on the exogenous variables selected, defined as a $(Z \times 1)$ vector - for this, see the pioneering work of Ramey and Shapiro (1998). The exogenous variables that may be included in the model as additional determinants of $\Gamma_{t}$, are - by definition - independent of the lagged values of $\Gamma_{t}$.

The panel VAR model augmented with a set of exogenous variables (PVARX) has the general form

$\gamma_{y, t}=v_{1 y}+\sum_{l=1}^{p} \Omega_{l, y} \Gamma_{t-l}+\sum_{l^{\prime}=0}^{q} \Psi_{l, y} \Phi_{t-l^{\prime}}+e_{1 y, t}$,

where $\Phi_{t}=v_{2}+\sum_{l=1}^{p^{x}} \vartheta_{l} \Phi_{t-l}+e_{2, t}$. 
In Eq. (10) $\Psi_{l, y}, l=0, \ldots \ldots$, , are $(Y \cdot X \times Z)$ matrices of the coefficients of the exogenous variables, $q$ represents potential lags of the exogenous variables, and $e_{1 y, t}$ and $e_{2, t}$ should be uncorrelated. By estimating Eqs. (10-11), we generate a system of simultaneous equations where each successive equation contains $W=Y \cdot X \cdot p+Z \cdot(q+1)+1$ estimated coefficients including the intercept; and the total number of coefficients generated by all the equations in the system amounts to $Y \cdot X \cdot W$. In this study we are dealing with a strongly balanced panel. Accordingly, in order to estimate the panel VARX models we use a GMM estimator (Canova \& Ciccarelli, 2013), and in this procedure we estimate consecutive equations in the system, instrumenting lagged differences with the differences and levels of $\gamma_{y, t}$ from the previous periods (Anderson and Hsiao, 1982; Hayakawa, 2016). Based on the GMM estimates, Wald tests can be conducted to verify the null hypothesis that one variable does not Granger-cause another (Granger, 1980). Typically, the estimation of consecutive panel VARX models is preceded by specifying an optimal lag order (Abrigo \& Love, 2016). As Andrews and Lu (2001) suggest, the model selection criteria (MSC) are commonly used standards such as the Akaike information criteria (AIC) (Akaike, 1969), the Bayesian information criteria (BIC) (Akaike, 1977; Schwarz, 1978) or the Hannan-Quinn information criteria (HQIC) (Hannan \& Quinn, 1979). To select the appropriate number of lags in our panel VAR models, we follow the Moment and Model Selection Criteria (MMSC) suggested by Andrews and Lu (2001). We assume an $x$-variate panel VAR of order $p$, sample size $n$, and $q$ lags of the dependent variables, where $J_{n}(x, p, q)$ is the Hansen $J$ statistic of overidentifying restrictions (Hansen, 1982). We choose the pair of vectors $(p, q)$ that minimises the following:

$\operatorname{MMSC}_{A I C, n}(x, p, q)=J_{n}\left(x^{2} p, x^{2} q\right)-2 k^{2}(|q|-|p|)$,

$\operatorname{MMSC}_{B I C, n}(x, p, q)=J_{n}\left(x^{2} p, x^{2} q\right)-(|q|-|p|) k^{2} \ln n$, $\operatorname{MMSC}_{H Q I C, n}(x, p, q)=J_{n}\left(x^{2} p, x^{2} q\right)-R k^{2}(|q|-|p|) \ln \ln n$.

Note that the pair of vectors $(p, q)$ that minimises the criteria defined in Eqs. (13-15) is only available if $q>p$. These information criteria (Eqs. 11-13) consist of a vector that minimises the modified AIC(MAIC), the modified BIC (MBIC) and the modified QIC information criteria (MQIC), which, conversely to the conventional information criteria based on the normal likelihood function, are calculated using a quasi-likelihood function (McCullagh and Nelder, 1989). Additionally, for model selection the coefficient of determination (CD) may be used, which captures the proportion of the total variation explained by the specific panel VAR model (Abrigo and Love, 2016). In contrast to the information criteria, the maximum value of the $\mathrm{CD}$ is considered to indicate the optimum number of lags. To conclude, the length of the lag in the panel VAR model should be chosen by maximising the $\mathrm{CD}$ and minimising the MAIC, MBIC and MQIC. If the results are inconclusive, then, as $\mathrm{Ng}$ and Perron (2001) suggest, the MAIC criterion should be considered. As for model validation and to draw valid conclusions basing on the selected PVAR models, we adopt impulse-response function (IRF) to know the response of one variable to an impulse of another variable. To solve these issues, using the causal ordering, the orthogonal zed impulse-response function is estimated and plotted (Becketti, 2013). Prior, to impulse-response function estimates, we check for the stability condition of the estimated panels and forecast-error variance decomposition. To ease interpretation, the stability condition is visualized using roots of the companion matrix that allows for fast check if given panel satisfies or not the stability condition (Aknouche, 2007; Abrigo \& Love, 2016a). In the paper we decide to adopt the panel vector-autoregression modelling, which so far has been relatively rarely used in macroeconomic studies. Some more recent examples of this method usage may be traced in works of, inter alia, Gnimasoun and Mignon (2016), Aminsano and Geweke (2017), Koop (2017), Sigmund et al. (2017) or Thach and Oanch (2018). Surely this 
method has certain advantages and limitations as always when qualitative in nature process are intended to be captured in numbers. One of the greatest advantages is that panel autoregression modelling approach allows for identifying dynamic interdependencies among variables. It additionally allows determining the spatial heterogeneity of objects and tracing at least in statistics - how changes in one variable may potentially affect changes in other variables across spatially dispersed and heterogenic units (e.g. countries) (Bagliano \& Morana, 2009; and Canova \& Ciccarelli, 2013). Moreover as claimed by scholars, the use of this approach allows for identifying shocks impact on macroeconomic process. Still, one of the drawbacks of the use of panel vector autoregression models is that estimated parameters are hard to interpret directly, which implies - in some cases, relatively weak value for, for instance, policy recommendation.

\section{The data}

This study focuses on economically backward countries, for which we aim to identify correlations between women's economic activity and the use of ICT. We have selected 64 countries (see Table 1 in the Appendix) classified by the Word Bank as low-income (per capita GNI at most \$995) or lower-middle-income (per capita GNI \$996-\$3,895). ${ }^{1}$ The period examined is 1990-2017, although for some countries the time series is shorter. We selected 10 variables for investigation. First is Internet Users $\left(\mathrm{IU}_{\mathrm{y}, \mathrm{t}}\right)$, the share of a country's population that uses the Internet. This variable includes both estimates and data on the proportion of the population using the Internet, based on national household surveys (the number should reflect the total population of the country, or at least individuals aged 5 and older; see the definition in WTI, 2016). These data are derived from the World Telecommunications/ICT Indicators database 2017. We use 7 different indicators of women`s participation in economic activities:

- Female employment in agriculture as share of total female employment (Agric $\mathrm{y}_{\mathrm{y}, \mathrm{t}}$ );

- The female youth employment rate (the percentage of women aged 15-24 who are employed (Empl15-24, $)$; the International Labour Organization generally considers ages 15-24 to be the youth population;

- Female self-employment as share of total female employment (Self $\mathrm{y}_{\mathrm{t}, \mathrm{t}}$ );

- Female vulnerable employment as share of total female employment (Vulner, ${ }_{\mathrm{y}, \mathrm{t}}$;

- Female wage and salaried workers as share of total female employment (Wage ${ }_{y, t}$ );

- Female contributing family workers as share of total female employment (Family $y, t)$;

- Female labour force as share of total labour force [Labor ${ }_{y, t}$ ).

All these statistics are extracted from the International Labour Organization ILOSTAT database (retrieved in November 2017), and basically they rely on modelled ILO estimates. According to the ILO (2013), self-employed workers are those who work on their own account or with one or a few partners or in cooperatives; their remuneration depends directly on the profits generated by the business they run. The category includes employers, ownaccount workers, members of producers' cooperatives and contributing family workers. The term 'vulnerable employment' refers to family workers and own-account workers who are usually employed 'under relatively precarious circumstances. ... [B] ecause contributing family workers and own-account workers are less likely to have formal work arrangements, access to benefits or social protection programmes and are more "at risk" to economic cycles, these are the statuses categorized as "vulnerable" (ILO 2013, p.28). We also use the indicator 'contributing family workers,' which covers those who are own-account workers and contribute to a 'market-oriented establishment' that is run by another person living in the

\footnotetext{
${ }^{1}$ See: https://blogs.worldbank.org/opendata/new-country-classifications-income-level-2018-2019 [accessed: Aug 2018].
} 
same household but cannot be considered a business partner because their commitment to the operation of the business is 'too low compared to the head of the firm' (see the ILO Current Guidelines ${ }^{2}$ ). Next, the term 'wage and salaried workers' refers to those who hold the type of jobs defined as 'paid employment jobs' and hold employment contracts. The last indicator shows the extent to which women are active in the total labour force. Additionally, we use two other indicators Female secondary school enrolment as a share of total school enrolment $\left(\right.$ SchoolSec $\left._{\mathrm{y}, \mathrm{t}}\right)$ and GDP per capita, PPP (constant 2011 international \$) $\left(\mathrm{GDP}_{\mathrm{y}, \mathrm{t}}\right)$. These statistics are derived from the World Development Indicators 2018 database.

\section{Empirical evidence}

\subsection{Graphical evidence}

We start our discussion on the interrelationships between ICT diffusion and women's economic empowerment by tracing the general trends in the variables examined. Figure 1 tracks all the variables from 1990 to 2017 and displays the general tendencies observed in developing countries. Figure 2 shows the correlations between ICT penetration rates and all the other variables. Additionally, the figure in Appendix 2 gives the density of the variables and changes in their distribution. The lines represent the values for 1990, 2000 and 2017. The trends in the average values (Figure 1) reflect significant changes in the Internet penetration rate - an increase of 25 percentage points - and in secondary school enrolment - an increase of 30 percentage points. Meanwhile, significantly, average GDP per capita almost doubled. Bearing in mind our main hypothesis of an impact of new technologies on changes in women's economic activity, we expect to find declines in female employment in agriculture, women contributing family members, women in vulnerable employment and/or selfemployed, and females aged 15-24 in employment. And in fact we do observe decreases in all these variables between 1990 and 2017, the sharpest falls coming in agricultural and youth employment (in both cases, -15 percentage points). Women's engagement in agricultural work plunged drastically in several countries: for instance, Burkina Faso (from $90.6 \%$ to 19.8\%), Papua New Guinea (from $68.8 \%$ to $15.4 \%$ ) and Lesotho (from $51.2 \%$ to $4.5 \%$ ). In a few others the decreases amounted to about $25 \%$. The share of women engaged in the agricultural sector did rise in 12 countries but insignificantly. The trends in the share of women working as contributing family workers, self-employed, and in vulnerable employment are similar. Although developments vary among countries, in the vast majority these indicators trended downward. Another interesting observation is that for four variables characterising female economic activity, until 2000 the trends are somewhat positive - in particular, see the share of women family workers, but all four variables began to decline from 2000 onward, demonstrating relatively rapid change in women's economic activity. Along with this, we find changes in women's engagement in formal labour market activities. Although the change is slight, it is positive. Women's share in the total labour force rose from an average of $41 \%$ to $42.4 \%$. The most significant shifts are in Benin, Bangladesh, Ivory Coast, Mali, Nigeria, Nepal, Sudan and El Salvador, where the share of women in the total labour force grew by approximately 7 percentage points. However, in some economies the tendency was the opposite, with the proportion of women in the labour market stagnating or even falling. This was the case, for instance, in such economies as Burkina Faso, Kyrgyzstan, India and Myanmar, where the female labour force share decreased by around 2-3 points. Finally, the last very positive change in the developing countries examined is a rise in

\footnotetext{
${ }^{2}$ See: https://www.ilo.org/global/statistics-and-databases/statistics-overview-and-topics/status-inemployment/current-guidelines/lang--en/index.htm [accessed: Aug 2018].
} 
women`s engagement in wage and salaried work, which rose on average from $25.5 \%$ to $30.6 \%$, with the most significant increases in Cambodia (from 3.8\% to 42.3\%), Myanmar (from $11.2 \%$ to $36.7 \%$ ) and Vietnam (from $12.3 \%$ to $35.8 \%$ ). These data suggest a very significant shift on the part of women from the informal to the formal sector, transitioning from self-employment or vulnerability to contracted and more stable jobs. However, there are also contrary cases, such as Morocco with a 17.3-point drop and Georgia with one of 23.9 points, plus eight other countries. This variable thus rose in 54 countries of the full sample of 64. Next, for the same period (1990-2017) we compare changes in each of the female-related variables examined with ICT penetration rates. Figure 2 visualises the correlations between consecutive pairs of variables. A first look reveals relatively irregular patterns, low correlations between the variables. Graphically, there is a positive and relatively strong correlation between per capita GDP and Internet penetration rates. The correlation coefficient is about 0.6 and is statistically significant. This result may reflect indirect causality between growth in ICT deployment and economic growth, as many claim. Next, the relationship between growth in ICT use and female secondary school enrolment is similar in direction and strength, which again might support the supposition that ICT boosts educational opportunities, if only indirectly. On the whole, girls' secondary school enrolment rose massively in the countries studied: in Bhutan from $20.7 \%$ to $87.8 \%$, in Bangladesh from $42.2 \%$ to $72.5 \%$, and in Tunisia from $39 \%$ to $97.8 \%$. This is a positive change, allowing girls to stay in school instead of entering the labour market as unskilled workers at permanent risk of vulnerability. Better education, narrowing the school gender gap, at least partially redresses the inequality in economic opportunity between men and women. If young women can attend high school, they automatically enter the labour market older and better qualified. This view is supported by the data on female youth employment ratios (ages 15-24), which declined on average by 4.5 percentage points, indicating a general trend of decreasing participation in economic activity by young women, hopefully paving the way to a broad improvement in the condition of women in developing countries. The largest declines in young women's labour market participation are observed in Burundi, Burkina Faso, Djibouti, Laos, Myanmar and Vietnam. In the remaining cases, the relationships between ICT deployment and the variables proxying for women's engagement in economic activity are negative and relatively weak. The correlation coefficients between Internet penetration rates and the shares of women working in agriculture, self-employed or vulnerable are $-0.33,-0.37$ and -0.36 respectively. These results show that during our sample period growing access to and use of ICT was accompanied by a declining share of women engaged in activities exposing them to high risk or characterised by low effective demand and low profits. Decreases in the share of women in vulnerable employment would seem to be of critical importance. The sharpest decreases are found in Cambodia (down 38 percentage points), Myanmar (26 points), and Vietnam (25 points), followed by Bangladesh, Djibouti, Uganda, Haiti, Kyrgyzstan and Mongolia, all with declines of around 15 points. However, a few of our sample countries also showed a rising share of women in vulnerable employment, but happily these increases were generally slight, except for Georgia, where the share rose by 23 points. Looking more closely at the data on women's self-employment, we see that it coincides quite well with vulnerable employment. In fact the correlation coefficient between these variables is 0.99: that is, being self-employed in an economically backward country 'automatically' makes women vulnerable in the labour market. Vulnerable workers are permanently exposed to a high risk of losing their job, they usually work in the informal economy with no contract and they ordinarily lack social and legal protection. Turning to the correlation between ICT deployment and the share of women working as contributing family workers, we observe that it is relatively weak, with a coefficient of -0.16 . In the full sample, the average fall in the share of the female population working as contributing family workers decreased by only 2.8 percentage points, which is not 
a significant change. On the one hand, in several countries there were massive declines, as in Mongolia (down 43 points), Vietnam (40 points), Rwanda (34 points) and Myanmar (37). In a number of other economies, however, the indicator rose significantly, such as Tunisia (50 points) and Nepal (48 points), to cite two.

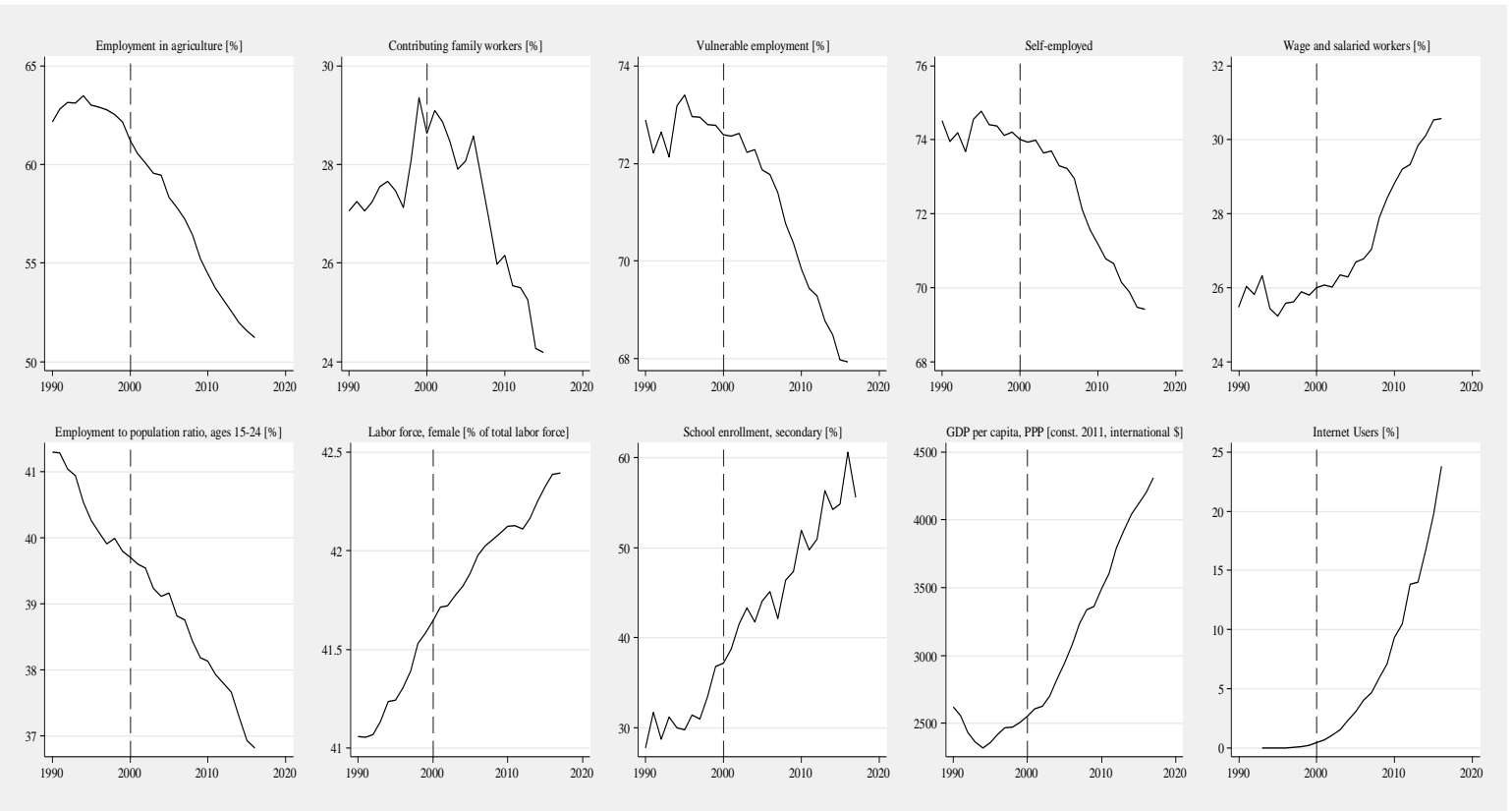

Figure 1. Changes in the averages of $I_{\mathrm{y}, t,}$, $\operatorname{Agric}_{\mathrm{y}, \mathrm{t}}$, Empl15-24 $_{\mathrm{y}, \mathrm{t}}$, Self $_{\mathrm{y}, \mathrm{t}}, \operatorname{Vulner}_{\mathrm{y}, \mathrm{t}}$, Wage $_{y, t}$, Family, t, Labory $y, t$, SchoolSec $_{y, t}$ and GDP $y, t$. 1990-2017 Source: Author`s elaboration
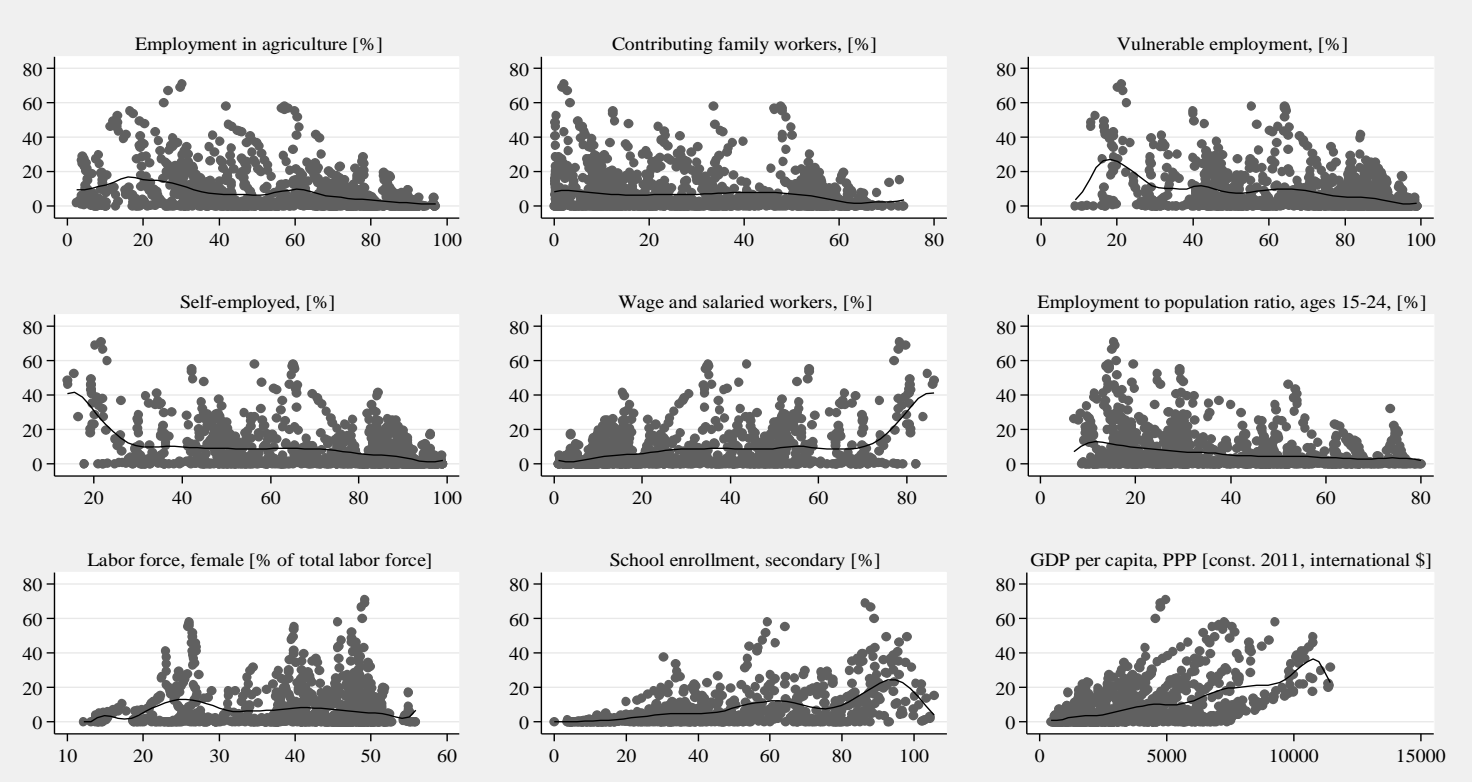

Figure 2. IU $_{y, t}$, versus Agric $y, t$, Empl15-24, $_{y, t}$, Self $y, t$, Vulner $_{y, t}$, Wage $y, t$, Family $_{y}, t$, Labory $_{\mathbf{y}, t}$, SchoolSec $_{\mathrm{y}, \mathrm{t}}$ and GDP , $_{\mathrm{t}}$ 1990-2017

Source: Author`s elaboration. Note: Kernel-weighted local polynomial smoothing applied; X and $Y$ axes: raw data 


\subsection{Panel regression results}

We now examine the relationships between women's economic activity and Internet use by means of panel random models and panel vector-autoregression models. The data and time span are the same as above. Apart from the commonly used panel random models, we will also employ a PVAR model to capture dynamic cross-country interdependencies and heterogeneity between ICT diffusion and other selected variables. Bearing the nature of these variables and the interdependencies among national economies in mind, we hypothesise that lagged variables in country $y_{1}$ may affect other domestic variables in country $y_{2}$. Increased flows of information, knowledge and technology have greatly heightened interdependencies among economies (Koop \& Korobilis, 2016).

These interlinkages may be essential factors in bidirectional causal effects, demonstrating global dependencies and transmission channels. Table 1 shows the estimates of panel random regressions of the quantitative relationships between changes in per capita GDP and the other variables. Table 2 shows the relationships between women's wage and salaried work and the other variables. We hypothesise that a positive effect of ICT and technological change in general on women's economic activity may be reflected indirectly in growth in national output and a rising share of female wage and salaried workers. Tables 3 and 4 summarise the results of panel vector-autoregression models, which are expected to reveal temporal and spatial causality between the variables. In Table 1's regressions of per capita GDP on the other variables, in order to control for potential collinearity among the variables included in consecutive specifications, we estimate mean variation inflation factors. All eight models estimated have similar R-squares, ranging from 0.41 to 0.53 , so we can argue that the independent variables only partially 'explain' the changes in gross per capita output. The results indicate that per capita GDP is positively associated with the share of Internet users $\left(I U_{y, t}\right)$. Although the correlation is relatively weak, it is nevertheless stable across successive specifications. As expected, there is also a positive and statistically significant relationship in the case of two other variables: Wage $y, t$ and SchoolSec $_{y, t}$. However, the correlation of GDP growth with the share of women in wage and salaried work is stronger than that with the share of girls in secondary school. These results should not be a surprise, however, given that the effects of education on a country's overall welfare generally emerge only with significant time lags. The correlation between GDP and Wage $\mathrm{y}_{\mathrm{t}, \mathrm{t}}$ is direct and shows that as more women leave self-employment and other types of vulnerable employment, this translates into faster growth. At the same, $\mathrm{GDP}_{\mathrm{y}, \mathrm{t}}$ is negatively correlated with all the remaining variables: Agric $\mathrm{y}_{\mathrm{y}, \mathrm{t}}$, Family $_{\mathrm{y}, \mathrm{t}}$, Vulner $\mathrm{y}, \mathrm{t}$, Self $_{\mathrm{y}, \mathrm{t}}$, Empl15-24, $4_{\mathrm{y}, \mathrm{t}}$ and Labor $\mathrm{y}, \mathrm{t}$. This coincides with our expectations, in that women's engagement in agriculture, family work, self-employment and vulnerable labour market positions is ordinarily associated with working in unproductive sectors characterised by very limited demand and generating low and unstable returns. The strongest and most stable relationships are those between $\operatorname{GDP}_{\mathrm{y}, \mathrm{t}}$ and Agric $\mathrm{y}_{\mathrm{t}, \mathrm{t}}$ and between $\mathrm{GDP}_{\mathrm{y}, \mathrm{t}}$ and Empl15$24_{y, t}$. Obviously, high employment rates in the agricultural sector do not generally coincide with high gross per capita income, given the generally low levels of investment and technological intensity in farming in the developing countries. Next, at first sight the negative relationship between GDP $_{y, t}$ and Empl15-24y,t might seem unfavourable, but this correlation should be read as meaning that where young women tend to stay in school rather than enter the labour market (usually informal) as low-paid unskilled workers, GDP performs better. 
Table 1. GDP versus selected determinants. Panel model estimates. Random effects. 19902017

\begin{tabular}{|c|c|c|c|c|c|c|c|c|}
\hline $\mathrm{GDP}_{\mathrm{y}, \mathrm{t}}$ & & & & & & & & \\
\hline & $\underset{(1)}{\text { RE_GDP }}$ & $\underset{(2)}{\text { RE_GDP }}$ & $\underset{(3)}{\text { RE_GDP }}$ & $\underset{(4)}{\text { RE_GDP }}$ & $\underset{(5)}{\text { RE_GDP }}$ & $\underset{(6)}{\text { RE_GDP }}$ & $\underset{(7)}{\text { RE_GDP }}$ & $\underset{(8)}{\text { RE_GDP }}$ \\
\hline $\mathrm{IU}_{\mathrm{y}, \mathrm{t}}$ & $\begin{array}{c}0.05 \\
{[0.00]}\end{array}$ & $\begin{array}{c}0.05 \\
{[0.00]}\end{array}$ & $\begin{array}{c}0.04 \\
{[0.00]}\end{array}$ & $\begin{array}{c}0.04 \\
{[0.00]}\end{array}$ & $\begin{array}{c}0.05 \\
{[0.00]}\end{array}$ & $\begin{array}{c}0.04 \\
{[0.00]}\end{array}$ & $\begin{array}{c}0.05 \\
{[0.00]}\end{array}$ & $\begin{array}{c}0.05 \\
{[0.00]}\end{array}$ \\
\hline Agric $_{\mathrm{y}, \mathrm{t}}$ & & $\begin{array}{c}-0.16 \\
{[0.00]}\end{array}$ & & & & $\begin{array}{c}-0.15 \\
{[0.02]}\end{array}$ & & \\
\hline Family $_{y, t}$ & & $\begin{array}{c}-0.03 \\
{[0.01]}\end{array}$ & & & & & $\begin{array}{c}-0.05 \\
{[0.01]}\end{array}$ & \\
\hline Vulner $_{\mathrm{y}, \mathrm{t}}$ & & $\begin{array}{c}-0.28 \\
{[0.06]}\end{array}$ & $\begin{array}{l}-0.007 \\
{[0.00]}\end{array}$ & & $\begin{array}{c}-0.39 \\
{[0.06]}\end{array}$ & & & \\
\hline Self $_{\mathrm{y}, \mathrm{t}}$ & & & & & & & & $\begin{array}{c}-0.13 \\
{[0.06]}\end{array}$ \\
\hline Wage $_{\mathrm{y}, \mathrm{t}}$ & $\begin{array}{c}0.22 \\
{[0.03]}\end{array}$ & & & $\begin{array}{c}0.01 \\
{[0.00]}\end{array}$ & & $\begin{array}{c}0.22 \\
{[0.02]}\end{array}$ & $\begin{array}{c}0.23 \\
{[0.03]}\end{array}$ & $\begin{array}{c}0.21 \\
{[0.02]}\end{array}$ \\
\hline $\begin{array}{l}\text { Empl15- } \\
24_{\mathrm{y}, \mathrm{t}}\end{array}$ & $\begin{array}{c}-0.28 \\
{[0.04]}\end{array}$ & & & & & $\begin{array}{c}-0.14 \\
{[0.03]}\end{array}$ & & $\begin{array}{c}-0.20 \\
{[0.03]}\end{array}$ \\
\hline Labor $_{\mathrm{y}, \mathrm{t}}$ & & & $\begin{array}{c}-0.02 \\
{[0.00]}\end{array}$ & & $\begin{array}{c}-0.69 \\
{[0.13]}\end{array}$ & & & \\
\hline $\begin{array}{l}\text { SchoolSe } \\
c_{y, t}\end{array}$ & $\begin{array}{c}\mathbf{0 . 0 8} \\
{[0.02]}\end{array}$ & & $\begin{array}{c}0.008 \\
{[0.00]}\end{array}$ & $\begin{array}{c}0.007 \\
{[0.00]}\end{array}$ & $\begin{array}{c}0.13 \\
{[0.01]}\end{array}$ & & $\begin{array}{c}0.09 \\
{[0.02]}\end{array}$ & \\
\hline $\begin{array}{l}\text { R-sq. } \\
\text { (overall) }\end{array}$ & 0.53 & 0.41 & 0.52 & 0.45 & 0.52 & 0.49 & 0.46 & 0.47 \\
\hline $\begin{array}{l}\text { Breuch- } \\
\text { Pagan } \\
\text { test } \\
\text { (prob> } \chi^{2} \\
\text { ) }\end{array}$ & $\begin{array}{c}4656 \\
{[0.00]}\end{array}$ & $\begin{array}{l}10007 \\
{[0.00]}\end{array}$ & $\begin{array}{c}4376 \\
{[0.00]}\end{array}$ & $\begin{array}{c}4779 \\
{[0.00]}\end{array}$ & $\begin{array}{c}4376 \\
{[0.00]}\end{array}$ & $\begin{array}{c}4971 \\
{[0.00]}\end{array}$ & $\begin{array}{c}4651 \\
{[0.00]}\end{array}$ & $\begin{array}{c}9932 \\
{[0.00]}\end{array}$ \\
\hline rho & 0.94 & 0.92 & 0.95 & 0.94 & 0.94 & 0.92 & 0.94 & 0.92 \\
\hline $\begin{array}{l}\text { Mean } \\
\text { VIF }\end{array}$ & 1.8 & 1.3 & 1.4 & 1.6 & 1.4 & 1.6 & 1.7 & 2.4 \\
\hline \# of obs. & 783 & 1288 & 783 & 783 & 783 & 1288 & 783 & 1288 \\
\hline
\end{tabular}

Source: Author's estimates. Note: for random-effects estimations standard errors are reported; constants included but not reported; statistically significant coefficients at the 5\% level in bold; all values are logs.

Table 2 summarises the results of regressing Wage W $_{\mathrm{t}}$ on the other variables. As in the previous case, we hypothesise that a positive impact of new technologies on women's economic activity may be demonstrated indirectly by rises in wage and salaried work. We expect that as countries advance technologically, more women become employees with payroll jobs rather than self-employed in low-productivity and vulnerable sectors. Conceptually, the results in Table 2 coincide with Table 1 . The dependent variable Wage $\mathrm{y}_{\mathrm{t}, \mathrm{t}}$ is strongly and positively correlated with $\mathrm{GDP}_{\mathrm{y}, \mathrm{t}}$ and $\mathrm{SchoolSec}_{\mathrm{y}, \mathrm{t}}$, which confirms our previous estimates. The correlation with $\mathrm{IU}_{\mathrm{y}, \mathrm{t}}$ is weak, but positive in most specifications. However, for the RE_Wage(1) model the R-square is 0.07 , indicating a null relationship between Wage $\mathrm{y}_{\mathrm{y}, \mathrm{t}}$ and $\mathrm{IU}_{\mathrm{y}, \mathrm{t}}$ across all the countries studied. As for the other explanatory variables, the correlations with Wage $_{y, t}$ are generally negative, supporting our previous results. Here, the coefficients estimated reveal somewhat direct links between increases in the proportion of women becoming wage or salary workers and decreases in the proportion engaged in agriculture, self-employed or contributing family workers. 
Table 2. Wage and salaried workers versus selected determinants. Panel model estimates. Random effects. 1990-2017

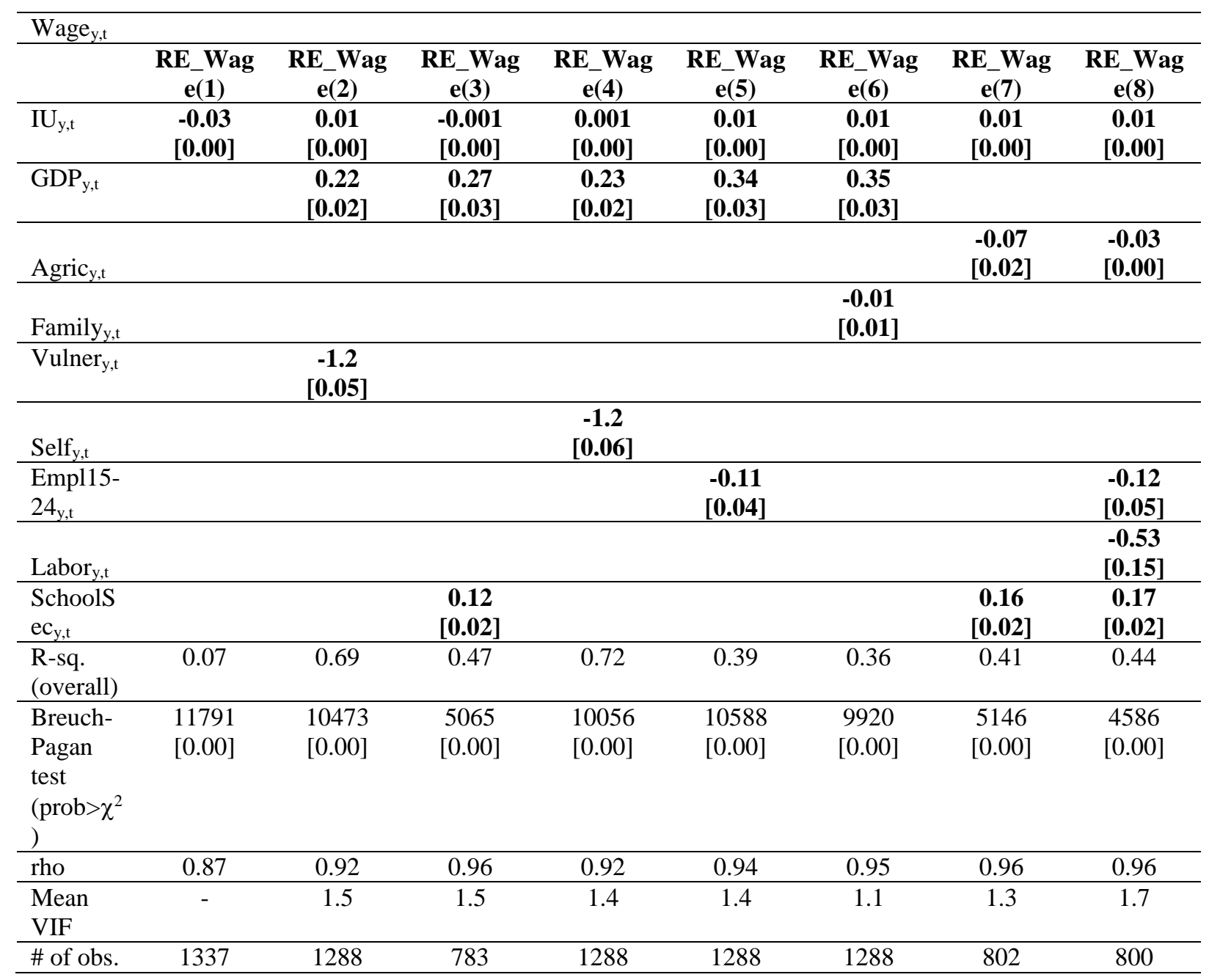

Source: Author's estimates. Note: for random-effects estimations standard errors are reported; constants included but not reported; the coefficients in bold are statistically significant at 5\% level in bold; all values are logs.

Finally, to trace causality between ICT use and female economic activity, we use panel vector-autoregressive models to capture possible dynamic cross-country interdependencies and heterogeneity with respect to the variables of interest. Tables 3 and 4 summarise the results of our estimates of the PVAR models and of Granger causality Wald tests. Before estimating the models, we conduct an analysis of their lag order using the AIC, modified BIC and modified HQIC criteria. The results unequivocally counsel 2-year-lag panel vector autoregression models (see Appendix 3). Choosing the order-lag for each model we follow general rule in this methods, and select that lag-order that satisfies the minimal value regarding selection criteria. In the next step we estimate 8 different specifications, each including the 2-year lags of the endogenous variables. After, each model estimation, we validate the results by estimating the impulse-response function (IRF) for each separate panel as well as forecast-error variance decompositions. All theses tests are provided in Appendix 4.

The PVAR results may be interpreted as the average responses of endogenous variables to changes in any variable after controlling for time-invariant characteristics. 
Table 3. Panel VAR estimates (I). 1990-2017

\begin{tabular}{|c|c|c|c|c|}
\hline & $\begin{array}{c}\gamma_{y, t}=A g r i c \\
\text { equation }\end{array}$ & $\begin{array}{c}\gamma_{y, t}=\text { Family } \\
\text { equation }\end{array}$ & $\begin{array}{c}\gamma_{y, t}=\text { Vulner } \\
\text { equation }\end{array}$ & $\begin{array}{c}\gamma_{y, t}=S e l f \\
\text { equation }\end{array}$ \\
\hline Agric(t-1) & $\begin{array}{c}0.82 \\
{[0.16]}\end{array}$ & & & \\
\hline $\operatorname{Agric}(\mathrm{t}-2)$ & $\begin{array}{c}0.14 \\
{[0.14]}\end{array}$ & & & \\
\hline Family(t-1) & & $\begin{array}{l}\mathbf{0 . 9 0} \\
{[0.07]}\end{array}$ & & \\
\hline Family(t-2) & & $\begin{array}{l}-0.008 \\
{[0.03]}\end{array}$ & & \\
\hline Vulner(t-1) & & & $\begin{array}{c}1.06 \\
{[0.11]}\end{array}$ & \\
\hline Vulner(t-2) & & & $\begin{array}{c}0.11 \\
{[0.07]}\end{array}$ & \\
\hline Self(t-1) & & & & $\begin{array}{c}0.99 \\
{[0.10]}\end{array}$ \\
\hline Self(t-2) & & & & $\begin{array}{c}0.11 \\
{[0.06]}\end{array}$ \\
\hline $\mathrm{IU}(\mathrm{t}-1)$ & $\begin{array}{l}-0.005 \\
{[0.00]}\end{array}$ & $\begin{array}{l}-0.003 \\
{[0.02]}\end{array}$ & $\begin{array}{l}0.004 \\
{[0.00]}\end{array}$ & $\begin{array}{l}0.001 \\
{[0.00]}\end{array}$ \\
\hline $\mathrm{IU}(\mathrm{t}-2)$ & $\begin{array}{l}0.002 \\
{[0.00]}\end{array}$ & $\begin{array}{l}-0.003 \\
{[0.02]}\end{array}$ & $\begin{array}{l}-0.003 \\
{[0.00]}\end{array}$ & $\begin{array}{l}-0.00 \\
{[0.00]}\end{array}$ \\
\hline \#obs. & 1128 & 1128 & 1128 & 1128 \\
\hline & $\begin{array}{l}\gamma_{y . t}=I U \\
\text { equation }\end{array}$ & $\gamma_{y . t}=I U$ equation & $\gamma_{y . t}=I U$ equation & $\gamma_{y . t}=I U$ equation \\
\hline Agric $(\mathrm{t}-1)$ & $\begin{array}{l}-1.11 \\
{[0.43]}\end{array}$ & & & \\
\hline Agric(t-2) & $\begin{array}{c}0.06 \\
{[0.33]} \\
\end{array}$ & & & \\
\hline Family(t-1) & & $\begin{array}{c}-0.82 \\
{[0.19]}\end{array}$ & & \\
\hline Family(t-2) & & $\begin{array}{c}0.07 \\
{[0.06]}\end{array}$ & & \\
\hline Vulner(t-1) & & & $\begin{array}{c}-2.67 \\
{[0.76]}\end{array}$ & \\
\hline Vulner(t-2) & & & $\begin{array}{c}-0.39 \\
{[0.41]}\end{array}$ & \\
\hline Self(t-1) & & & & $\begin{array}{l}-2.64 \\
{[0.68]}\end{array}$ \\
\hline Self(t-2) & & & & $\begin{array}{c}-0.33 \\
{[0.30]}\end{array}$ \\
\hline $\mathrm{IU}(\mathrm{t}-1)$ & $\begin{array}{c}0.93 \\
{[0.04]}\end{array}$ & $\begin{array}{c}0.88 \\
{[0.06]}\end{array}$ & $\begin{array}{c}0.91 \\
{[0.05]}\end{array}$ & $\begin{array}{c}0.92 \\
{[0.05]}\end{array}$ \\
\hline $\mathrm{IU}(\mathrm{t}-2)$ & $\begin{array}{c}-0.07 \\
{[0.03]}\end{array}$ & $\begin{array}{c}-0.01 \\
{[0.05]}\end{array}$ & $\begin{array}{c}-0.04 \\
{[0.03]}\end{array}$ & $\begin{array}{c}-0.06 \\
{[0.03]} \\
\end{array}$ \\
\hline \multicolumn{5}{|c|}{ Granger causality Wald test $-\chi^{2}\left[\right.$ Prob $\left.>\chi^{2}\right]$} \\
\hline & Equation & Equation & Equation & Equation \\
\hline & $\underset{\mathrm{y}, \mathrm{t}}{\mathrm{Agric}} \quad \mathrm{IU}_{\mathrm{y}, \mathrm{t}}$ & $\begin{array}{c}\text { Family } \\
y, t\end{array}$ & Vulner $_{\mathrm{y}, \mathrm{t}}$ & Self $_{\mathrm{y}, \mathrm{y}}$ \\
\hline $\begin{array}{l}\text { Agric/Family/ } \\
\text { Vulner/Self } \\
\text { equation }\end{array}$ & $\begin{array}{c}1.69 \\
{[0.42]}\end{array}$ & $\begin{array}{c}4.32 \\
{[0.11]}\end{array}$ & $\begin{array}{c}1.36 \\
{[0.51]}\end{array}$ & $\begin{array}{c}0.29 \\
{[0.86]}\end{array}$ \\
\hline IU equation & $\begin{array}{c}15.2 \\
{[0.00]}\end{array}$ & $\begin{array}{c}17.6 \\
{[0.00]}\end{array}$ & $\begin{array}{c}13.1 \\
{[0.00]}\end{array}$ & $\begin{array}{c}15.2 \\
{[0.00]}\end{array}$ \\
\hline
\end{tabular}

Source: Authors`calculations. Note: GMM estimator applied. Number of lags based on AIC, BIC and HQIC criteria. First or second lags of the explanatory variables used as 
instruments. SEs below coefficients. Model validation parameters and checks are provided in the Appendix 4 (see there for eigenvalues stability condition checks presented as roots of the companion matrices graphs, forecast-error variance decomposition as well as impulse response functions (IRF) computed using 200 Monte Carlo simulations). The coefficients in bold are statistically significant at 5\% level. GMM weight matrix robust. All values are logs.

Table 4. Panel VAR estimates (II). 1990-2017

\begin{tabular}{|c|c|c|c|c|}
\hline & $\begin{array}{c}\gamma_{y, t}=\text { Wage } \\
\text { equation }\end{array}$ & $\begin{array}{l}\gamma_{y, t} \\
=\underset{\quad \text { Empl15 }-24}{\quad \text { equation }}\end{array}$ & $\begin{array}{c}\gamma_{y, t}=\text { Labor } \\
\text { equation }\end{array}$ & $\begin{array}{c}\gamma_{y, t}=\begin{array}{c}\text { Schoolsec } \\
\text { equation }\end{array} \\
\text { equan }\end{array}$ \\
\hline Wage(t-1) & $\begin{array}{c}1.18 \\
{[0.49]} \\
\end{array}$ & & & \\
\hline Wage(t-2) & $\begin{array}{c}0.07 \\
{[0.05]} \\
\end{array}$ & & & \\
\hline Empl15-24(t-1) & & $\begin{array}{c}0.98 \\
{[0.13]}\end{array}$ & & \\
\hline Empl15-24(t-2) & & $\begin{array}{c}0.04 \\
{[0.08]}\end{array}$ & & \\
\hline Labor(t-1) & & & $\begin{array}{c}0.96 \\
{[0.12]}\end{array}$ & \\
\hline SchoolSec(t-1) & & & & $\begin{array}{c}\mathbf{0 . 8 1} \\
{[0.05]}\end{array}$ \\
\hline $\mathrm{IU}(\mathrm{t}-1)$ & $\begin{array}{c}0.002 \\
{[0.01]} \\
\end{array}$ & $\begin{array}{l}-0.002 \\
{[0.00]} \\
\end{array}$ & $\begin{array}{c}0.00 \\
{[0.00]}\end{array}$ & $\begin{array}{c}\mathbf{0 . 0 2} \\
{[0.00]}\end{array}$ \\
\hline $\mathrm{IU}(\mathrm{t}-2)$ & $\begin{array}{l}-0.009 \\
{[0.01]}\end{array}$ & $\begin{array}{l}0.001 \\
{[0.00]}\end{array}$ & - & - \\
\hline \#obs. & 1128 & 1128 & 1194 & 602 \\
\hline & $\gamma_{y, t}=I U$ equation & $\gamma_{y, t}=I U$ equation & $\begin{array}{l}\gamma_{y, t}=I U \\
\text { equation }\end{array}$ & $\gamma_{y, t}=I U$ equation \\
\hline Wage(t-1) & $\begin{array}{l}6.56 \\
{[5.3]}\end{array}$ & & & \\
\hline Wage (t-2) & $\begin{array}{c}0.08 \\
{[0.53]}\end{array}$ & & & \\
\hline Empl15-24(t-1) & & $\begin{array}{c}-3.1 \\
{[0.95]}\end{array}$ & & \\
\hline Empl15-24(t-2) & & $\begin{array}{c}0.71 \\
{[0.51]}\end{array}$ & & \\
\hline Labor(t-1) & & & $\begin{array}{c}25.9 \\
{[12.5]}\end{array}$ & \\
\hline SchoolSec(t-1) & & & & $\begin{array}{c}1.7 \\
{[0.48]}\end{array}$ \\
\hline $\mathrm{IU}(\mathrm{t}-1)$ & $\begin{array}{c}\text { 0.81 } \\
{[0.15]}\end{array}$ & $\begin{array}{c}0.97 \\
{[0.04]}\end{array}$ & $\begin{array}{c}0.76 \\
{[0.06]}\end{array}$ & $\begin{array}{c}0.68 \\
{[0.06]}\end{array}$ \\
\hline $\mathrm{IU}(\mathrm{t}-2)$ & $\begin{array}{c}-0.12 \\
{[0.12]} \\
\end{array}$ & $\begin{array}{c}-0.10 \\
{[0.03]}\end{array}$ & - & - \\
\hline \multicolumn{5}{|c|}{ Granger causality Wald test $-\chi^{2}\left[\right.$ Prob $\left.>\chi^{2}\right]$} \\
\hline & Equation & Equation & Equation & Equation \\
\hline & Wage $_{\mathrm{y}, \mathrm{t}}$ & $\underset{24_{y, t}}{\text { Empl15- }} \quad$ IU & Labor $_{\mathrm{y}, \mathrm{t}} \quad \mathrm{IU}$ & SchoolSec $_{y, t} \quad$ IU \\
\hline $\begin{array}{l}\text { Wage/Empl15- } \\
\text { 24/Labor/SchoolSec } \\
\text { equation }\end{array}$ & $\begin{array}{c}0.56 \\
{[0.75]}\end{array}$ & $\begin{array}{c}0.89 \\
{[0.64]}\end{array}$ & $\begin{array}{c}0.07 \\
{[0.78]}\end{array}$ & $\begin{array}{c}8.2 \\
{[0.00]}\end{array}$ \\
\hline IU equation & $\begin{array}{c}1.56 \\
{[0.46]}\end{array}$ & $\begin{array}{c}12.5 \\
{[0.00]}\end{array}$ & $\begin{array}{c}4.3 \\
{[0.03]}\end{array}$ & $\begin{array}{c}11.8 \\
{[0.00]}\end{array}$ \\
\hline
\end{tabular}


Source: Authors`calculations. Note: GMM estimator applied. Number of lags selected based on AIC, BIC and HQIC criteria. First or second lags of the explanatory variables used as instruments. SEs below coefficients. Model validation parameters and checks are provided in the Appendix 4 (see there for eigenvalues stability condition checks, roots of the companion matrices graphs, forecast-error variance decomposition as well as impulse response functions (IRF) computed using 200 Monte Carlo simulations). The coefficients in bold are statistically significant at $\mathbf{5 \%}$ level. GMM weight matrix robust. All values are $\operatorname{logs}$.

The results are quite mixed; the coefficients do not unequivocally support our hypothesis of a causal link between ICT deployment and women's economic activity. Table 3 reports the estimates of system equations on causality between ICT and Agric $\mathrm{y}_{\mathrm{t}, \mathrm{t}}$, Family $\mathrm{y}_{\mathrm{y}, \mathrm{t}}$, Vulner $_{\mathrm{y}, \mathrm{t}}$ and Self $\mathrm{y,t}$. These results indicate that changes in $\mathrm{IU}_{\mathrm{y}, \mathrm{t}}$ as a proxy for the share of the population with access to and using Internet do not serve to predict changes in any of the variables listed above. In other words, our estimates do not allow us to conclude that shifts in Internet use indicate future changes in the proportion of women working in agriculture, being family workers, or being self-employed. Nor do we find statistically significant estimates regarding vulnerable employment. The Granger causality tests support these findings, again indicating no such causality. However, our estimates of the successive $\gamma_{y, t}=I U$ equations (Table 3) do suggest a sort of reverse causality between ICT and Agric y,t, $_{\text {, Family }}, \mathrm{t}$, Vulner $_{\mathrm{y}, \mathrm{t}}$ and Self $f_{y, t}$. Looking at the coefficients, we can see that changes - decreases - in the values of Agric $_{y, t}$, Family $y, t$, Vulner $_{y, t}$ and Self $f_{y, t}$ could potentially predict growth in Internet penetration rates. The strongest correlations (both negative) are for vulnerable employment $(-2.67)$ and self-employment (-2.64), with 1-year lags. Bearing in mind the foregoing results indicating relatively strong associations between ICT and girls' secondary school enrolment, we may hypothesise that thanks to better education, which is enhanced by technological advances, women tend to move into wage and salaried employment, abandoning various kinds of vulnerable work. Evidently, these relationships are not straightforward. The Wald tests on the $\gamma_{y, t}=I U$ equations indicate that in this case there $i s$ Granger causality. Therefore, changes in Agric $_{\mathrm{y}, \mathrm{t}}$, Family $_{\mathrm{y}, \mathrm{t}}$, Vulner $\mathrm{y}_{\mathrm{t}, \mathrm{t}}$ and Self $\mathrm{y,t}$ may be used to predict changes in Internet use in the developing countries studied. Similar conclusions can be derived from the PVAR estimates provided in Table 4. Here, we control for four other variables - Wage $\mathrm{y}_{\mathrm{t}, \mathrm{t}}$ Empl15-24y,t, Labor $_{\mathrm{y}, \mathrm{t}}$ and $\mathrm{SchoolSec}_{\mathrm{y}, \mathrm{t}}$ - to trace possible causality between them and Internet penetration rates. The estimates returned are similar to those reported in Table 3 relating ICT to the different variables. The successive coefficients estimated do not support the hypothesis that changes in the share of women in wage and salaried work, the female youth employment rate, or the share of women in the labour force overall can be predicted by changes in ICT penetration rates. This view is also supported by the Wald tests. The only exception is female secondary school enrolment, whereas the coefficient for IU(t-1) suggests that past changes in Internet penetration rates do predict changes in girls' school attendance. The Wald test also supports the hypothesis that $\mathrm{IU}_{\mathrm{y}, \mathrm{t}}$ Granger-causes changes in $\mathrm{SchoolSec}_{\mathrm{y}, \mathrm{t}}$. Finally, the coefficients for the $\gamma_{y, t}=I U$ equations produce results analogous to those summarised in Table 3. We find a kind of reverse causality; that is, shifts and improvements in female economic participation and empowerment probably foster more and broader Internet use throughout the economy and the society. The Wald tests support this supposition, excepting only the Wage $_{y, t}$ variable. Highly mixed though they are, these results to some extent support the hypothesis that ICT deployment is also enhanced by increasing women's economic activity, which in turn is significantly supported by widespread deployment of ICT. Hence, it can be argued on the one hand that ICT deployment permits and fosters female economic education and through that channel economic activity and on the other that changes in 
women`s economic situation may drive further technological deployment. Thus there may be a kind of synergy. Undoubtedly, these relationships are bidirectional and there exists a reverse causal loop.

\section{Conclusions}

This study has examined, from a macro perspective, the association between ICT deployment in an economy, women`s engagement in labour markets, and economic growth in 64 developing countries from 1990 to 2017 . The study essentially had a twofold research aim. First, we intended to examine the main trends in seven variables selected to proxy for women`s engagement in economic activity, and also look at trends in ICT penetration rates, per capita GDP, and female secondary school enrolment. Second, using panel random regression models and panel vector autoregression models, we examined the statistical correlations between the variables. The study has shown that during the 28 years considered our sample countries underwent substantial changes in material economic welfare, as per capita GDP almost doubled, and in Internet penetration rates, which jumped from practically nil in 1990 to an average of some $25 \%$ in 2017. In addition, as can be clearly seen in Figure 1, many countries experienced drastic declines in women's agricultural work, female youth employment, and the share of women serving as contributing family workers. At the same time, we observe upward trends in girls' secondary school enrolment and women's wage and salaried work. Using panel random effects regressions, we hypothesised that the positive effects of ICT deployment on women's economic activity may be traced indirectly via economic growth and via an increasing share of women in wage and salaried positions. The results indicate positive associations between economic growth and female secondary school enrolment and wage and salaried work. At the same time we identified relatively strong negative correlations of economic growth with female employment in agriculture and female youth employment . As for Internet users, we have found the relationship to be positive and statistically significant but relatively weak. Regressing wage and salaried work on the remaining variables, we found mixed effects for Internet penetration rates, a relatively strong negative association with female youth employment and a strong positive relationship with secondary school enrolment. Finally, to verify the interdependencies among the variables we estimated panel vector autoregressions (PVAR). Unfortunately, no robust conclusions could be drawn from the estimates of the PVAR models, the coefficients appearing to be fairly random with no regularities emerging. Wald tests of Granger causality showed that changes in ICT deployment cannot predict changes in the proxies for women's economic activity. The statistical linkages between ICT deployment and the variables representing women's engagement in economic activity undeniably are bidirectional. It is not possible to encapsulate them in one single equation. We wish to emphasise that all these results require very careful interpretation. We are fully aware, first, that the statistical correlations reported may be spurious and, second, that the structural changes in women's employment and economic activity are part of a complex process driven by factors that are hard to quantify or even capture. It was not our intention to say that the diffusion and deployment of ICTs is the sole factor driving social and economic changes in developing countries. Obviously such changes are slow and sometimes hard to identify or trace in the short run. Hopefully, this preliminary inquiry can pave the way for future research, which potentially could concentrate on unveiling country specific conditions and prerequisites which enable or hinder higher women access to labour markets and engagement in valued added creation. Surely, these country-wise conditions are broad field of interest for scholars and policy makers, especially if bearing in mind the fact that they vary extensively among regions. Needless to say that getting into more profound and detailed research on country-specific barriers on female weak engagement in 
labour markets and different forms of formal economic activities would give a broader insight into our knowledge letting explore the issues more deeply.

\section{Acknowledgement}

This research is part of Project no.2015/19/B/HS4/03220 financed by the National Science Centre, Poland.

\section{References}

Abrigo, M. R. \& Love, I. (2016). Estimation of panel vector autoregression in Stata. Stata Journal, 16(3), 778-804.

Abrigo, M. R., \& Love, I. (2016a). Estimation of panel vector autoregression in stata: A package of programs. University of Hawaii. Working paper, (16-2).

Afrah, S. H. \& Fabiha, S. T. (2017). Empowering Women Entrepreneurs through Information and Communication Technology (ICT): A Case Study of Bangladesh. Management, 7(1), 1-6.

Afshar, H. (Ed.). (2016). Women and empowerment: Illustrations from the Third World. Springer.

Akaike, H. (1969). Fitting autoregressive models for prediction. Annals of the Institute of Statistical Mathematics, 21(1), 243-247.

Akaike, H. (1977). On entropy maximization principle, in P. R. Krishnaiah, (ed.) Applications of Statistics. Amsterdam: North-Holland, pp. 27-41.

Aknouche, A. (2007). Causality conditions and autocovariance calculations in PVAR models. Journal of Statistical Computation and Simulation, 77(9), 769-780.

Allen, S. \& Truman, C. (2016). Women in business: Perspectives on women entrepreneurs. Routledge.

Amisano, G., \& Geweke, J. (2017). Prediction using several macroeconomic models. Review of Economics and Statistics, 99(5), 912-925.

Anderson, T. W. \& Hsiao, C. (1982). Formulation and estimation of dynamic models using panel data. Journal of Econometrics, 18(1), 47-82.

Andersson, A. \& Hatakka, M. (2017). Victim, Mother, or Untapped Resource? Discourse Analysis of the Construction of Women in ICT Policies. Information Technologies \& International Development, 13, 15.

Andrews, D. W. \& Lu, B. (2001). Consistent model and moment selection procedures for GMM estimation with application to dynamic panel data models. Journal of Econometrics, 101(1), 123-164.

Bagliano, F. C., \& Morana, C. (2009). International macroeconomic dynamics: A factor vector autoregressive approach. Economic Modelling, 26(2), 432-444.

Bandiera, O., Buehren, N., Burgess, R., Goldstein, M., Gulesci, S., Rasul, I. \& Sulaiman, M. (2017). Women"s empowerment in action: Evidence from a randomized control trial in Africa. World Bank.

Becketti, S. (2013). Introduction to time series using Stata (pp. 176-182). College Station, TX: Stata Press.

Benería, L., Berik, G. \& Floro, M. (2015). Gender, development and globalization: economics as if all people mattered. Routledge.

Bresnahan, T. F. \& Trajtenberg, M. (1995). General purpose technologies "Engines of growth"?. Journal of econometrics, 65(1), 83-108.

Buvinic, M. \& Furst-Nichols, R. (2014). Promoting women"s economic empowerment: what works? The World Bank. 
Canova, F. \& Ciccarelli, M. (2009). Estimating multicountry VAR models. International Economic Review, 50(3), 929-959.

Canova, F., \& Ciccarelli, M. (2013). Panel Vector Autoregressive Models: A Survey 2 The views expressed in this article are those of the authors and do not necessarily reflect those of the ECB or the Eurosystem. In VAR Models in Macroeconomics-New Developments and Applications: Essays in Honor of Christopher A. Sims (pp. 205-246). Emerald Group Publishing Limited.

Castells, M., Fernandez-Ardevol, M., Qiu, J. L. \& Sey, A. (2009). Mobile communication and society: A global perspective. MIT Press.

Clark, G. (2008). A farewell to alms: a brief economic history of the world. Princeton University Press.

Cleveland, W. S. (1979). Robust locally weighted regression and smoothing scatterplots. Journal of the American statistical association, 74(368), 829-836.

Cornwall, A. (2016). Women"s empowerment: What works? Journal of International Development, 28(3), 342-359.

Dées, S. \& Guntner, J. (2014). Analysing and forecasting price dynamics across euro area countries and sectors: A panel VAR approach. European Central Bank Working Paper Series, 1724.

Drucker, P. (2017). The age of discontinuity: Guidelines to our changing society. Routledge.

Fielden, S. L., Davidson, M. J., Gale, A. W. \& Davey, C. L. (2000). Women in construction: the untapped resource. Construction Management \& Economics, 18(1), 113-121.

Gaddis, I. \& Klasen, S. (2014). Economic development, structural change, and women"s labor force participation. Journal of Population Economics, 27(3), 639-681.

Gnimassoun, B., \& Mignon, V. (2016). How do macroeconomic imbalances interact? Evidence from a panel VAR analysis. Macroeconomic Dynamics, 20(7), 1717-1741.

Granger, C. W. (1980). Testing for causality: a personal viewpoint. Journal of Economic Dynamics and control, 2, 329-352.

Hafkin, N. J. \& Huyer, S. (2006). Cinderella or cyberella?: Empowering women in the knowledge society. Kumarian Press, Incorporated.

Hayakawa, K. (2016). Improved GMM estimation of panel VAR models. Computational Statistics \& Data Analysis, 100, 240-264.

Hannan, E. J. \& Quinn, B. G. (1979). The determination of the order of an autoregression. Journal of the Royal Statistical Society. Series B (Methodological), 41(2), 190-195.

Hansen, L. P. (1982). Large sample properties of generalized method of moments estimators. Econometrica: Journal of the Econometric Society, 50(4), 1029-1054.

Hanna, N. K., Guy, K. \& Arnold, E. (1995). Information technology diffusion: Experience of industrial countries and lessons for developing countries. World Bank Staff Working Paper (1995). Washington DC The World Bank.

Helpman, E. \& Trajtenberg, M. (1996). Diffusion of general purpose technologies (No. w5773). National bureau of economic research.

ILO (2013). Guide to the Millennium Development Goals Employment Indicators. International Labour Office.

Islam, M. S. (2015). Impact of ICT on women empowerment in South Asia. Journal of Economic \& Financial Studies, 3(03), 80-90.

ITU World Telecommunication/ICT Indicators database 2017.

Jovanovic, B. \& Rousseau, P. L. (2005). General purpose technologies. Handbook of economic growth, 1, 1181-1224.

Kabeer, N. (2017). Economic pathways to women"s empowerment and active citizenship: what does the evidence from Bangladesh tell us? The Journal of Development Studies, 53(5), 649-663. 
Kabir, N. (2016). Women"s economic empowerment and inclusive growth: labour markets and enterprise development. School of Oriental and African Studies, UK.

Kaur, H., Lechman, E. \& Marszk, A. (Eds.). (2017). Catalyzing development through ICT adoption: the developing world experience. Springer.

Klasen, S., Lechtenfeld, T. \& Povel, F. (2015). A feminization of vulnerability? Female headship, poverty, and vulnerability in Thailand and Vietnam. World Development, 71, 36-53.

Klasen, S. (2018). What explains uneven female labor force participation levels and trends in developing countries? (No. 246). Courant Research Centre: Poverty, Equity and Growth-Discussion Papers.

Klasen, S. (2018a). The Impact of Gender Inequality on Economic Performance in Developing Countries. Annual Review of Resource Economics, 10, 279-298.

Koop, G. (2017). Bayesian methods for empirical macroeconomics with big data. Review of Economic Analysis, 9(1), 33-56.

Koop, G. \& Korobilis, D. (2016). Model uncertainty in panel vector autoregressive models. European Economic Review, 81, 115-131.

Lechman, E. (2015). ICT Diffusion in Developing Countries. Springer International.

Lindio-McGovern, L., \& Wallimann, I. (2016). Globalization and third world women: Exploitation, coping and resistance. Routledge.

Maddala, G. S. \& Lahiri, K. (2009). Introduction to econometrics. Wiley.

McCullagh, P. \& Nelder, J. A. (1989). Generalized Linear Models (Second Edition). Chapman and Hall/CRC.

Ng, S. \& Perron, P. (2001). Lag length selection and the construction of unit root tests with good size and power. Econometrica: Journal of the Econometric Society, 69(6), 15191554.

Ocampo, S. \& Rodríguez, N. (2012). An introductory review of a structural VAR-X estimation and applications. Revista Colombiana de Estadística, 35(3), 479-508.

Ortiz Rodríguez, J., \& Pillai, V. K. (2019). Advancing support for gender equality among women in Mexico: Significance of labor force participation. International Social Work, 62(1), 172-184.

Perez, C. \& Soete, L. (1988). Catching up in technology: entry barriers and windows of opportunity. Technical change and economic theory, 458-479.

Pryer, J. A. (2017). Poverty and vulnerability in Dhaka slums: the urban livelihoods study. Routledge.

Ramey, V. A. \& Shapiro, M. D. (1998). Costly capital reallocation and the effects of government spending. Carnegie-Rochester Conference Series on Public Policy, 48, 145-194.

Ranga, M. \& Etzkowitz, H. (2010). Athena in the world of techne: The gender dimension of technology, innovation and entrepreneurship. Journal of technology management \& innovation, 5(1), 1-12.

Sachs, C. E. (2018). Gendered fields: Rural women, agriculture, and environment. Routledge.

Shapiro, C., Carl, S., \& Varian, H. R. (1998). Information rules: a strategic guide to the network economy. Harvard Business Press.

Sigmund, M., Gunter, U., \& Krenn, G. (2017). How Do Macroeconomic and Bank-specific Variables Influence Profitability in the Austrian Banking Sector? Evidence from a Panel Vector Autoregression Analysis. Economic Notes: Review of Banking, Finance and Monetary Economics, 46(3), 555-586.

Schwarz, G. (1978). Estimating the dimension of a model. The Annals of Statistics, 6(2), 461464. 
Thach, N. N., \& Oanh, T. T. K. (2018, January). Effect of Macroeconomic Factors on Capital Structure of the Firms in Vietnam: Panel Vector Auto-regression Approach (PVAR). In International Conference of the Thailand Econometrics Society (pp. 502-516). Springer, Cham.

Tsani, S., Paroussos, L., Fragiadakis, C., Charalambidis, I. \& Capros, P. (2015). Female labor force participation and economic development. In Economic and Social Development of the Southern and Eastern Mediterranean Countries (pp. 303-318). Springer.

Valente, T. W. (1996). Social network thresholds in the diffusion of innovations. Social networks, 18(1), 69-89.

Verick, S. (2014). Female labor force participation in developing countries. IZA World of Labor.

Verick, S. (2018). Female labor force participation and development. IZA World of Labor. 


\section{Appendix 1. List of sample countries}

\begin{tabular}{llll}
\hline Afghanistan & Ethiopia & Mauritania & Tajikistan \\
\hline Angola & Gambia & Moldova & Tanzania \\
\hline Bangladesh & Georgia & Mongolia & Togo \\
\hline Benin & Ghana & Morocco & Uganda \\
\hline Bhutan & Guinea-Bissau & Mozambique & Ukraine \\
\hline Bolivia & Haiti & Myanmar & Vietnam \\
\hline Burkina Faso & Honduras & Nepal & Zambia \\
\hline Burundi & India & Nicaragua & Zimbabwe \\
\hline Cambodia & Indonesia & Niger & \\
\hline Cameroon & Ivory Coast & Nigeria & \\
\hline Central African Republic & Kenya & Pakistan & \\
\hline Chad & Kyrgyz Republic & Papua New Guinea & \\
\hline Comoros & Laos & Philippines & \\
\hline Congo, Dem. Rep. & Lesotho & Rwanda & \\
\hline Congo, Rep. & Liberia & Somalia & \\
\hline Djibouti & Madagascar & Sri Lanka & \\
\hline Egypt & Malawi & Sudan & \\
\hline El Salvador & Mali & Swaziland & \\
\hline Eritrea & & & \\
\hline
\end{tabular}

\section{Appendix 2}

Density representations of IU $\mathrm{y}_{\mathrm{t}, \mathrm{t}}$, Agric $\mathrm{y}_{\mathrm{t}, \mathrm{t}}$, Empl15-24y,t , Self $_{\mathrm{y}, \mathrm{t}}$, Vulner $\mathrm{y}_{\mathrm{t}, \mathrm{t}}$, Wage $\mathrm{y}_{\mathrm{y}, \mathrm{t}}$, Familyy,t, Labory $_{\mathrm{y}, \mathrm{t}}, \mathrm{SchoolSec}_{\mathrm{y}, \mathrm{t}}$ and GDP $\mathrm{y,t}$. 1990, 2000 and 2017

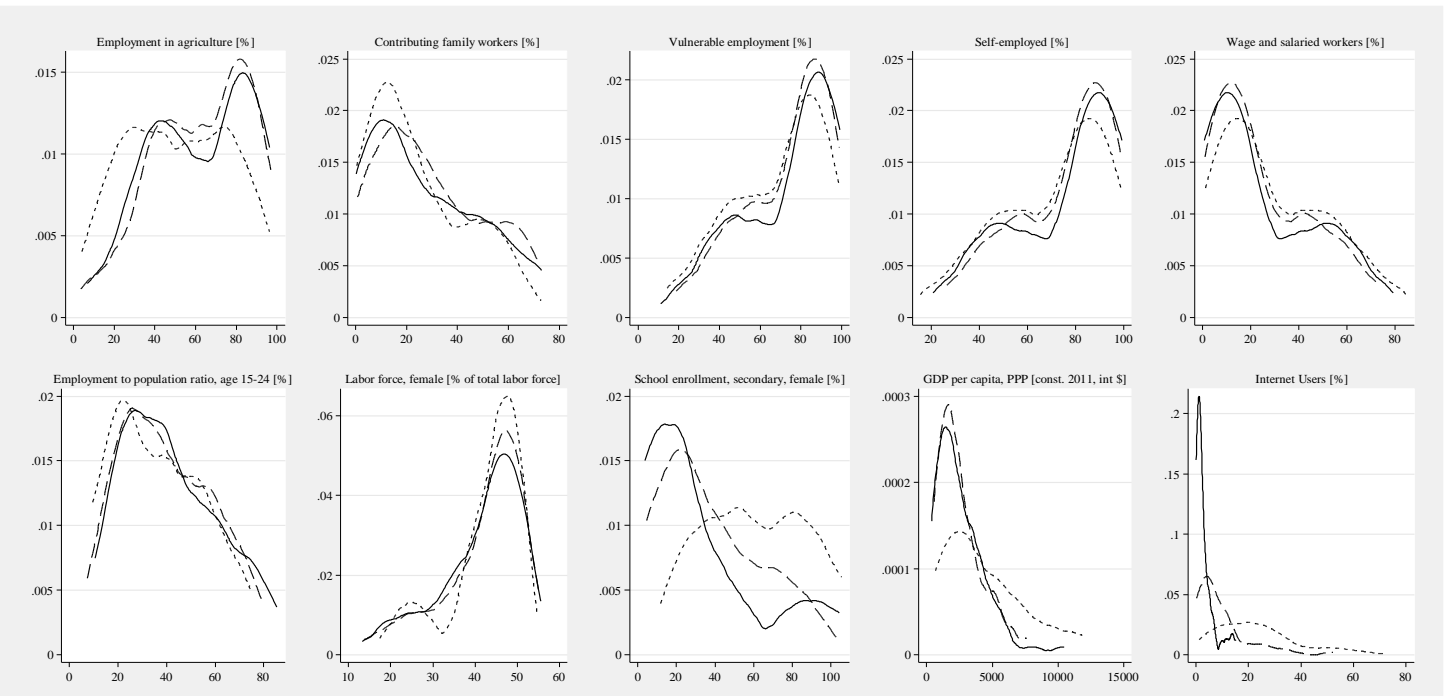

Source: Author`s elaboration. Note: solid line - 1990 (or 1991); long-dash line - 2000; shortdash line -2017. For $\mathrm{IU}_{\mathrm{y}, \mathrm{t}}$ - density lines for 2005, 2010 and 2016; for density representations, Kernel epanechnikov applied; bandwidth: default 


\section{Appendix 3}

Order selection criteria for the panel VAR models

\begin{tabular}{|c|c|c|c|c|c|}
\hline Lag order & CD & $\begin{array}{l}\text { Hansen's J } \\
\text { [J p-value] }\end{array}$ & MBIC & MAIC & MQIC \\
\hline \multicolumn{6}{|c|}{ IU/Agric } \\
\hline 1 & 0.99 & $42.1[0.00]$ & 10.1 & -67.1 & -19.3 \\
\hline 2 & 0.99 & $13.1[0.36]$ & -10.9 & -68.7 & -33.1 \\
\hline 3 & 0.99 & $8.6[0.37]$ & -7.3 & -45.8 & -22.1 \\
\hline 4 & 0.99 & $2.7[0.59]$ & -5.2 & -24.5 & -12.6 \\
\hline \multicolumn{6}{|c|}{ IU/Empl15-24 } \\
\hline 1 & 0.99 & $34.9[0.00]$ & 2.9 & -74.2 & -26.5 \\
\hline 2 & 0.99 & $11.3[0.49]$ & -12.6 & -70.4 & -34.7 \\
\hline 3 & 0.99 & $8.4[0.39]$ & -7.6 & -46.2 & -22.3 \\
\hline 4 & 0.99 & $2.5[0.63]$ & -5.4 & -24.7 & -12.8 \\
\hline \multicolumn{6}{|c|}{ IU/Family } \\
\hline 1 & 0.99 & $32.6[0.00]$ & 0.64 & -76.5 & -28.8 \\
\hline 2 & 0.99 & $15.6[0.21]$ & -8.3 & -66.2 & -30.4 \\
\hline 3 & 0.99 & $9.1[0.33]$ & -6.9 & -45.4 & -21.3 \\
\hline 4 & 0.99 & $0.68[0.95]$ & -7.3 & -26.6 & -14.7 \\
\hline \multicolumn{6}{|c|}{ IU/Labor } \\
\hline 1 & 0.99 & $21.5[0.15]$ & -10.6 & -87.5 & -39.8 \\
\hline 2 & 0.99 & $9.2[0.68]$ & -14.8 & -72.6 & -36.8 \\
\hline 3 & 0.99 & $5.3[0.71]$ & -10.6 & -49.2 & -25.3 \\
\hline 4 & 0.99 & $0.63[0.95]$ & -7.3 & -26.6 & -14.7 \\
\hline \multicolumn{6}{|c|}{ IU/SchoolSec } \\
\hline 1 & 0.99 & $14.7[0.54]$ & -17.3 & -75.4 & -40.6 \\
\hline 2 & 0.99 & $10.9[0.53]$ & -13.0 & -56.5 & -30.5 \\
\hline 3 & 0.99 & $7.2[0.51]$ & -8.7 & -37.8 & -20.4 \\
\hline 4 & 0.99 & $3.0[0.55]$ & -4.9 & -19.5 & -10.8 \\
\hline \multicolumn{6}{|c|}{ IU/Self } \\
\hline 1 & 0.99 & $43.8[0.00]$ & -65.3 & 11.8 & -17.6 \\
\hline 2 & 0.99 & $14.3[0.28]$ & -67.5 & -9.7 & -31.7 \\
\hline 3 & 0.99 & $8.1[0.42]$ & -46.5 & -7.9 & -22.6 \\
\hline 4 & 0.99 & $1.9[0.74]$ & -25.3 & -6.1 & -13.4 \\
\hline \multicolumn{6}{|c|}{ IU/Vulner } \\
\hline 1 & 0.99 & $43.1[0.00]$ & -65.9 & 11.1 & -18.3 \\
\hline 2 & 0.99 & $13.6[0.2]$ & -68.2 & -10.3 & -32.4 \\
\hline 3 & 0.99 & $7.8[0.45]$ & -46.7 & -8.2 & -22.9 \\
\hline 4 & 0.99 & $1.7[0.78]$ & -25.5 & -6.2 & -13.6 \\
\hline \multicolumn{6}{|c|}{ IU/Wage } \\
\hline 1 & 0.99 & $31.2[0.01]$ & -77.8 & -0.7 & -30.2 \\
\hline 2 & 0.99 & $12.8[0.38]$ & -69.1 & -11.2 & -33.3 \\
\hline 3 & 0.99 & $10.7[0.21]$ & -43.8 & -5.2 & -19.9 \\
\hline 4 & 0.99 & $2.1[0.71]$ & -25.2 & -5.8 & -13.2 \\
\hline
\end{tabular}

Source: Author`s calculations. 


\section{Appendix 4}

PVAR stability condition check

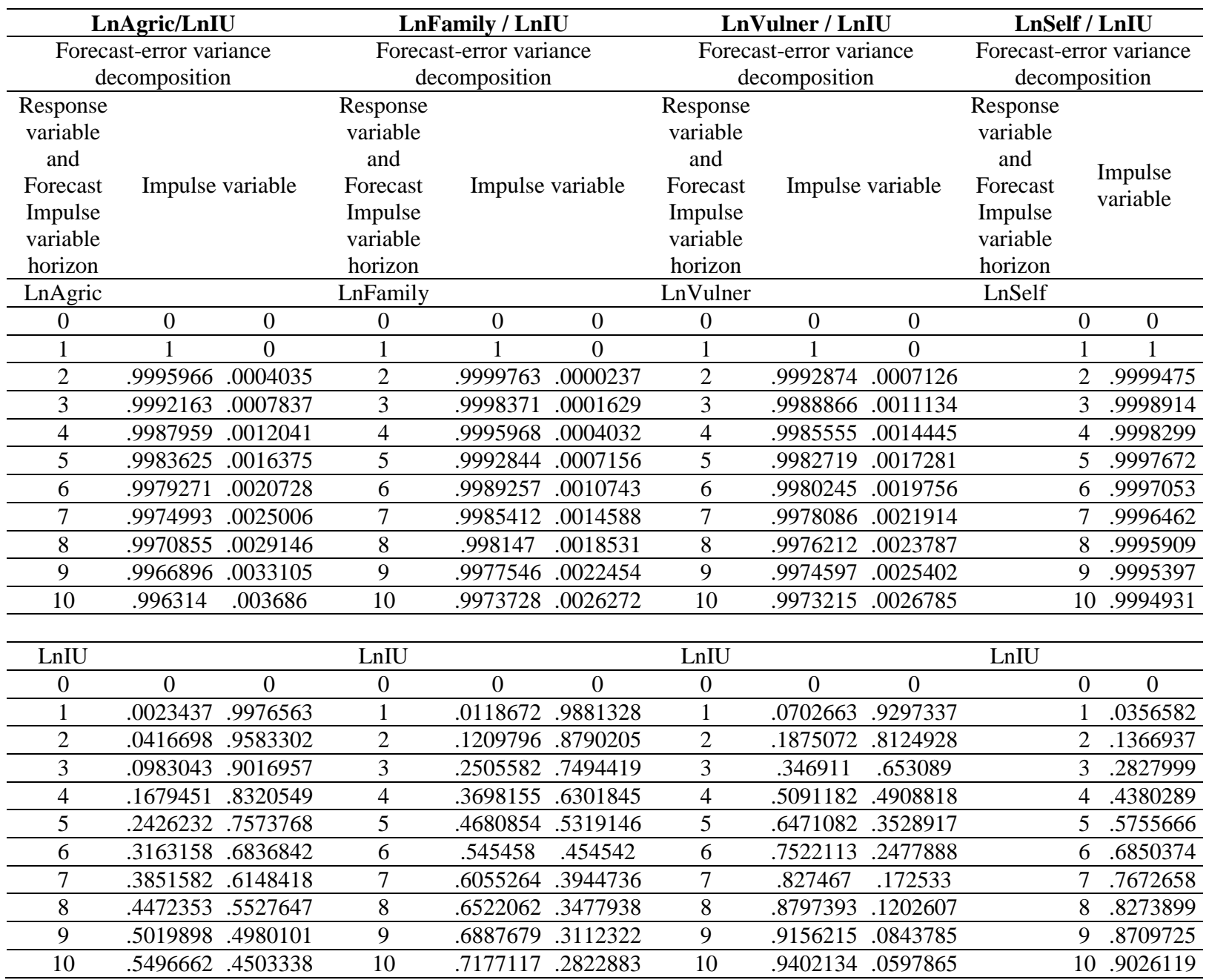

Source: Author`s estimates.

\begin{tabular}{|c|c|c|c|c|c|c|c|c|c|}
\hline \multicolumn{2}{|c|}{ LnWage / LnIU } & \multicolumn{3}{|c|}{ LnLaborForce / LnIU } & \multicolumn{2}{|c|}{ LnWage / LnIU } & \multicolumn{3}{|c|}{ LnSchool / LnIU } \\
\hline \multicolumn{2}{|c|}{$\begin{array}{l}\text { Forecast-error variance } \\
\text { decomposition }\end{array}$} & \multicolumn{3}{|c|}{$\begin{array}{c}\text { Forecast-error variance } \\
\text { decomposition }\end{array}$} & \multicolumn{2}{|c|}{$\begin{array}{l}\text { Forecast-error variance } \\
\text { decomposition }\end{array}$} & \multicolumn{3}{|c|}{$\begin{array}{c}\text { Forecast-error variance } \\
\text { decomposition }\end{array}$} \\
\hline $\begin{array}{l}\text { Response } \\
\text { variable } \\
\text { and } \\
\text { Forecast } \\
\text { Impulse } \\
\text { variable } \\
\text { horizon } \\
\end{array}$ & $\begin{array}{l}\text { Impulse } \\
\text { variable }\end{array}$ & $\begin{array}{c}\text { Response } \\
\text { variable } \\
\text { and Forecast } \\
\text { Impulse } \\
\text { variable } \\
\text { horizon }\end{array}$ & Impulse & variable & $\begin{array}{l}\text { Response } \\
\text { variable } \\
\text { and } \\
\text { Forecast } \\
\text { Impulse } \\
\text { variable } \\
\text { horizon }\end{array}$ & $\begin{array}{l}\text { Impulse } \\
\text { variable }\end{array}$ & $\begin{array}{c}\text { Response } \\
\text { variable } \\
\text { and Forecast } \\
\text { Impulse } \\
\text { variable } \\
\text { horizon }\end{array}$ & Impulse & variable \\
\hline LnWage & & LnLaborForce & & & LnWage & & LnSchoolSec & & \\
\hline 0 & 0 & 0 & 0 & 0 & 0 & 0 & 0 & 0 & 0 \\
\hline 1 & 1 & 1 & 1 & 0 & 1 & 1 & 1 & 1 & 0 \\
\hline 2 & .9998647 & 2 & .9998247 & .0001754 & 2 & .9998647 & 2 & .9705371 & .0294629 \\
\hline 3 & $\begin{array}{l}3.9996296 \\
\end{array}$ & 3 & .9991733 & .0008267 & 3 & .9996296 & 3 & .974332 & .025668 \\
\hline 4 & $4 \quad .9986848$ & 4 & .9981198 & .0018803 & 4 & .9986848 & 4 & .9516888 & .0483112 \\
\hline 5 & .9974181 & 5 & .996825 & .0031749 & 5 & .9974181 & 5 & .9583763 & .0416237 \\
\hline 6 & .9961199 & 6 & .9954197 & .0045803 & 6 & .9961199 & 6 & .9475716 & .0524283 \\
\hline 7 & $7 \quad .9949335$ & 7 & .9939924 & .0060076 & 7 & .9949335 & 7 & .9556003 & .0443998 \\
\hline 8 & $8 \quad .9939135$ & 8 & .9926 & .0073999 & 8 & .9939135 & 8 & .9514246 & .0485755 \\
\hline 9 & $\begin{array}{ll}9 & .9930682 \\
\end{array}$ & 9 & .9912763 & .0087236 & 9 & .9930682 & 9 & .9590852 & .0409148 \\
\hline 10 & $\begin{array}{ll}0 & .9923843 \\
\end{array}$ & 10 & .9900398 & .0099603 & 10 & .9923843 & 10 & .958047 & .041953 \\
\hline
\end{tabular}


RECENT ISSUES IN ECONOMIC DEVELOPMENT

\begin{tabular}{|c|c|c|c|c|c|c|c|c|c|c|}
\hline LnIU & & & $\mathrm{LnIU}$ & & & LnIU & & LnIU & & \\
\hline & 0 & 0 & 0 & 0 & 0 & 0 & 0 & 0 & 0 & 0 \\
\hline & 1 & .3755482 & 1 & .0030629 & .996937 & 1 & .3755482 & 1 & .593168 & 406832 \\
\hline & 2 & .6237512 & 2 & .142072 & .857928 & 2 & .6237512 & 2 & .6441941 & .3558059 \\
\hline & 3 & .7859138 & 3 & .2634737 & .7365263 & 3 & .7859138 & 3 & .6764247 & .3235752 \\
\hline & 4 & .8782812 & 4 & .3539468 & .6460532 & 4 & .8782812 & 4 & .7382383 & .2617617 \\
\hline & 5 & .9284052 & 5 & .4244202 & .5755798 & 5 & .9284052 & 5 & .76168 & .23832 \\
\hline & 6 & .9555703 & 6 & .4809147 & .5190853 & 6 & .9555703 & 6 & .8053491 & .1946508 \\
\hline & 7 & .9705165 & 7 & .5268553 & .4731446 & 7 & .9705165 & 7 & .8232939 & .176706 \\
\hline & 8 & .9788895 & 8 & .5645515 & .4354485 & 8 & .9788895 & 8 & .8535306 & .1464693 \\
\hline & 9 & .9836544 & 9 & .5957156 & .4042843 & 9 & .9836544 & 9 & .8674082 & .1325918 \\
\hline & 10 & .9863974 & 10 & .6216651 & .3783349 & 10 & .9863974 & 10 & .8887808 & .1112191 \\
\hline
\end{tabular}

Source: Author`s estimates.

Impulse response functions (IRF) - graphs for separate panels

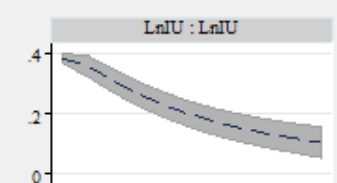

LnAgric : LnIU

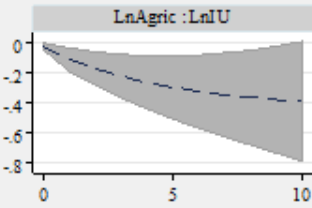

LnIU : LnIU

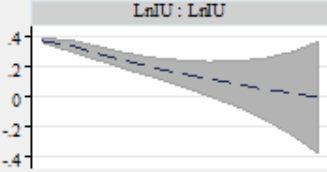

LnVuher: LnIU

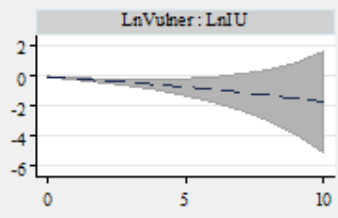

LnIU : LnAgric

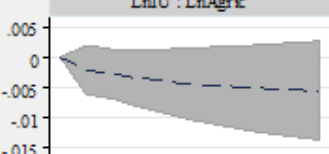

LnAgric : LnAgric

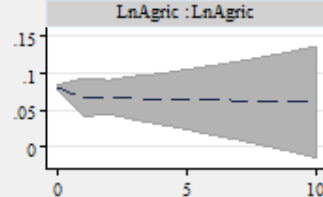

LnIU : LnVulner

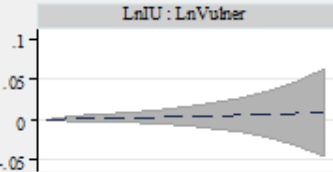

LnVulner : LnVu her

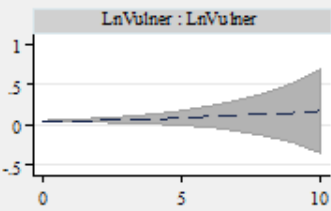

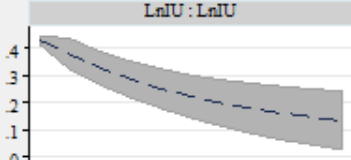

LnFamily : LnIU

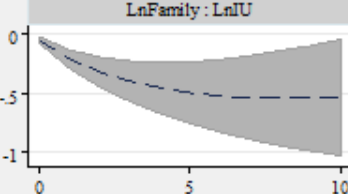

LnIU : LnIU

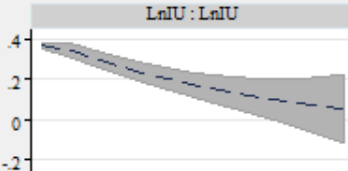

LnSelf : LriU

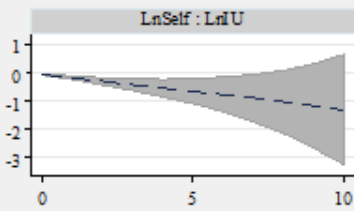

LnIU : LrFamily

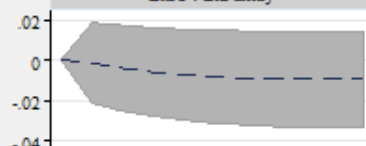

LnFamily : LnFamily

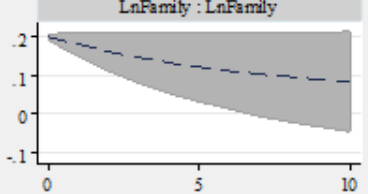

LnIU: LnSelf

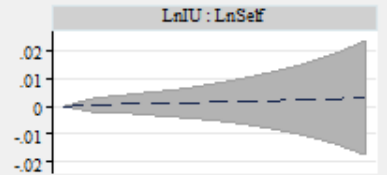

LnSelf : LnSelf

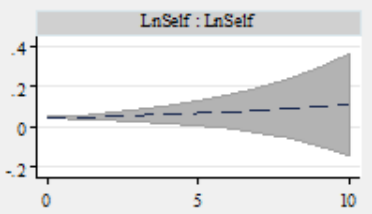

Source: Author`s elaboration. 

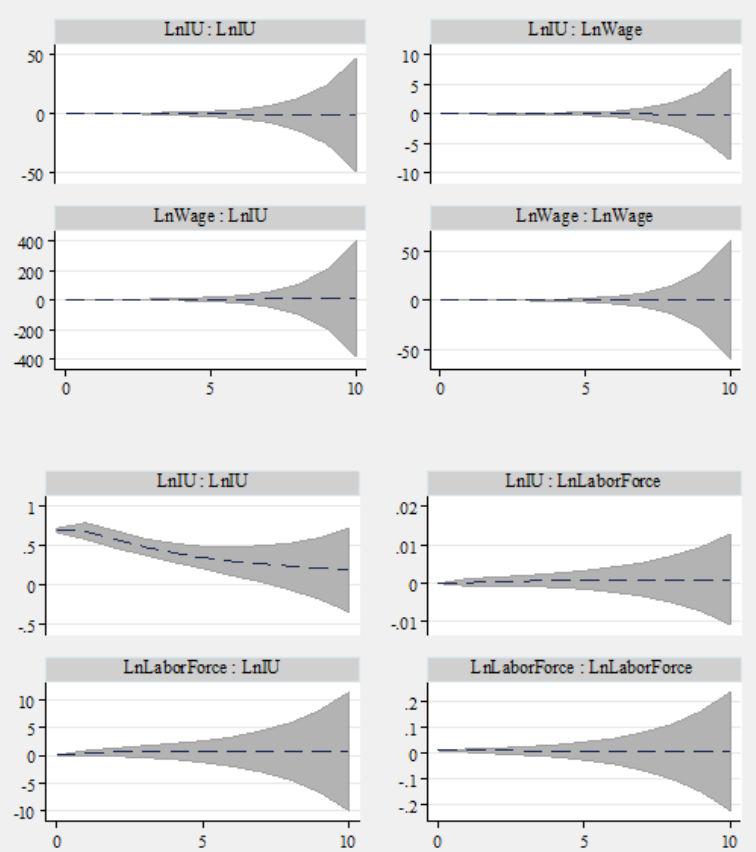
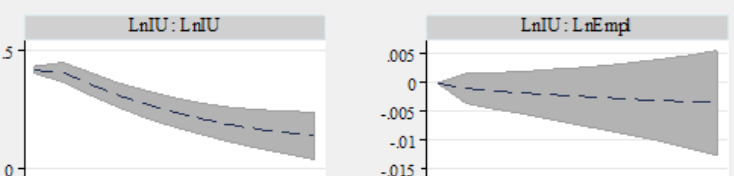

LnEmpl : LnIU
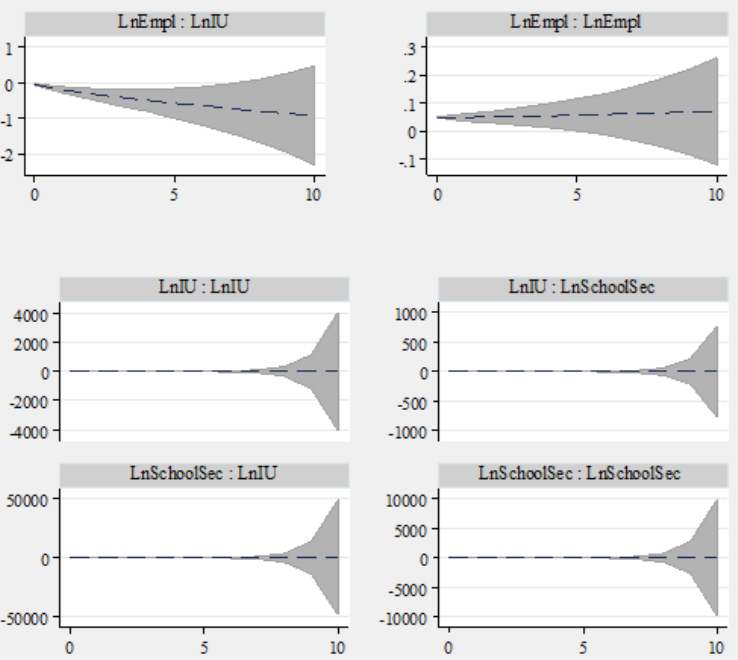

Source: Author`s elaboration.

Roots of the companion matrices graphs for separate panels / eigenvalues stability condition checks
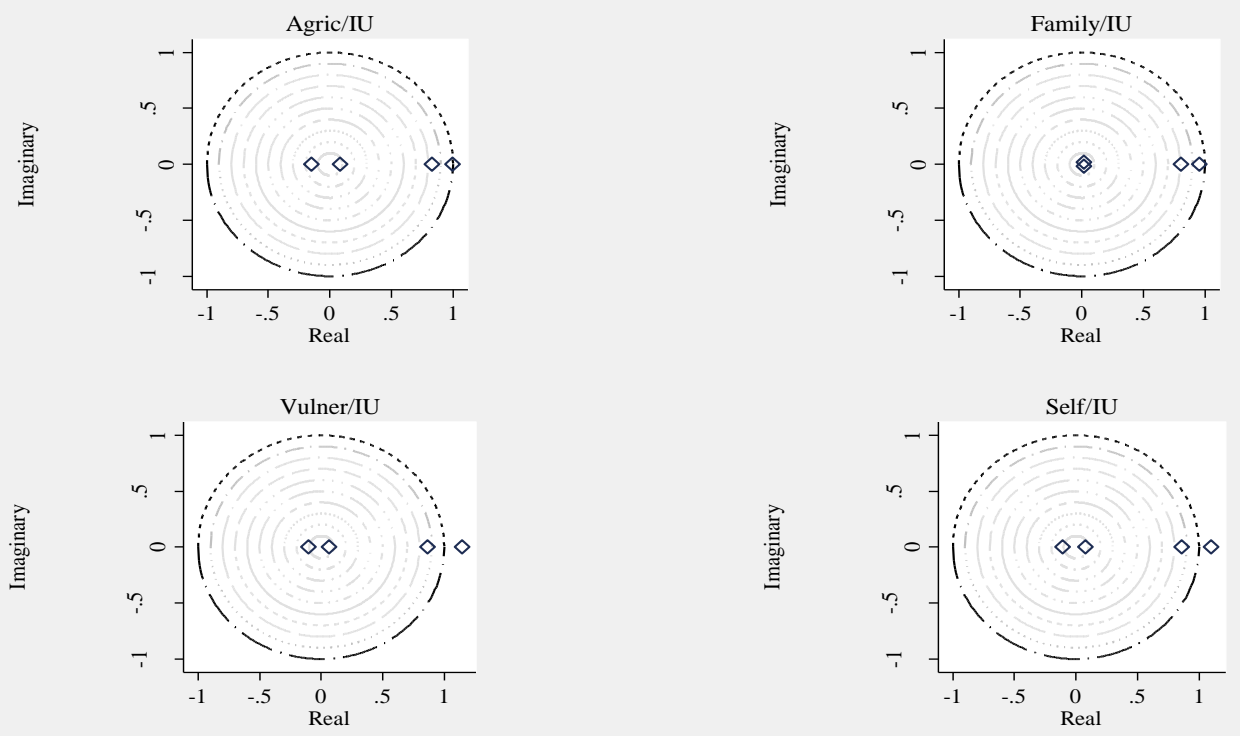

Source: Author`s elaboration. 

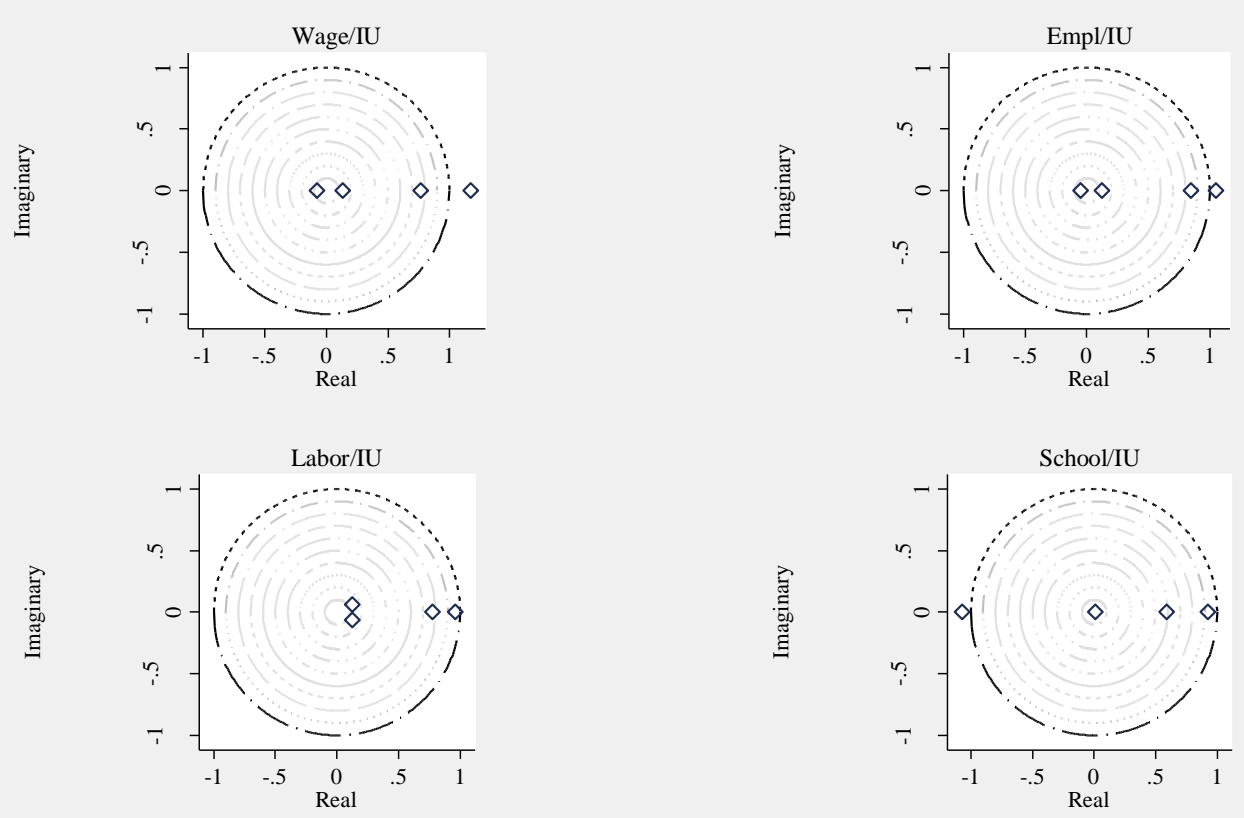

Source: Author`s elaboration. 